\title{
Potential for Improving Potency and Specificity of Reovirus Oncolysis with Next-Generation Reovirus Variants
}

\author{
Adil Mohamed ${ }^{1}$, Randal N. Johnston ${ }^{2}$ and Maya Shmulevitz ${ }^{1, *}$ \\ Received: 19 September 2015; Accepted: 18 November 2015; Published: 1 December 2015 \\ Academic Editors: E. Antonio Chiocca and Martine L.M. Lamfers \\ 1 Department of Medical Microbiology and Immunology, University of Alberta, Edmonton, AB T6G 2E1, \\ Canada; adilm@ualberta.ca \\ 2 Department of Biochemistry and Molecular Biology, Cumming School of Medicine, University of Calgary, \\ Calgary, AB T2N 4N1, Canada; rnjohnst@ucalgary.ca \\ * Correspondence: shmulevi@ualberta.ca; Tel.: +1-780-492-0623
}

\begin{abstract}
Viruses that specifically replicate in tumor over normal cells offer promising cancer therapies. Oncolytic viruses (OV) not only kill the tumor cells directly; they also promote anti-tumor immunotherapeutic responses. Other major advantages of OVs are that they dose-escalate in tumors and can be genetically engineered to enhance potency and specificity. Unmodified wild type reovirus is a propitious OV currently in phase I-III clinical trials. This review summarizes modifications to reovirus that may improve potency and/or specificity during oncolysis. Classical genetics approaches have revealed reovirus variants with improved adaptation towards tumors or with enhanced ability to establish specific steps of virus replication and cell killing among transformed cells. The recent emergence of a reverse genetics system for reovirus has provided novel strategies to fine-tune reovirus proteins or introduce exogenous genes that could promote oncolytic activity. Over the next decade, these findings are likely to generate better-optimized second-generation reovirus vectors and improve the efficacy of oncolytic reotherapy.
\end{abstract}

Keywords: reovirus; oncolytic virus; cancer; attachment; uncoating; replication; reverse genetics

\section{Introduction}

\subsection{Reovirus Naturally Infects the Small Intestine}

Mammalian orthoreovirus (MRV, herein referred to as reovirus) is a non-enveloped, icosahedral virus in the Reoviridae family. Reovirus poses little-to-no threat as a human pathogen, but has been used as a model system to improve our understanding of viruses and cells. The first Respiratory Enteric Orphan (REO) virus was isolated from healthy children in the 1950s [1,2]. Three prototypic serotypes of reovirus have since been well characterized: serotype 1 Lang (T1L), serotype 2 Jones (T2J), and serotype 3 Dearing (T3D). Reovirus is ubiquitous, with field isolates readily found in water bodies around the world, in addition to human, bovine, porcine, and murine fecal samples [3-8]. Reovirus genomes are composed of 10 dsRNA segments, and consequently natural isolates of reovirus tend to be genome reassortants. Humans are exposed to reovirus during childhood, resulting in up to $100 \%$ seropositivity among adults [9-11]. While other members of the Reoviridae family, such as orbiviruses and rotaviruses, cause gastrointestinal disease in livestock and humans respectively, reovirus has not been associated with disease during natural infection of humans or animals.

Reovirus has evolved some remarkable strategies to survive in, and even exploit the unique and harsh conditions of the intestine. Intestinal epithelial cells are polarized, with specialized 
apical membranes coated by a thick glycoprotein layer that conceals surface receptors and creates a barrier to viruses. Reovirus therefore exploits the antigen-transporting activity of specialized microfold epithelial (M-) cells to gain access to the basolateral membranes of intestinal epithelial cells [12-17]. Both M-cells and enterocytes stain positive by immunohistochemistry in reovirus-fed mice. Trimeric $\sigma 1$ cell attachment proteins protrude from reovirus vertices, and facilitates binding to $\alpha 2-3$-linked sialic acid on M-cells [13] and to Junction Associated Molecules (JAM-A) [18] on basolateral epithelial membranes.

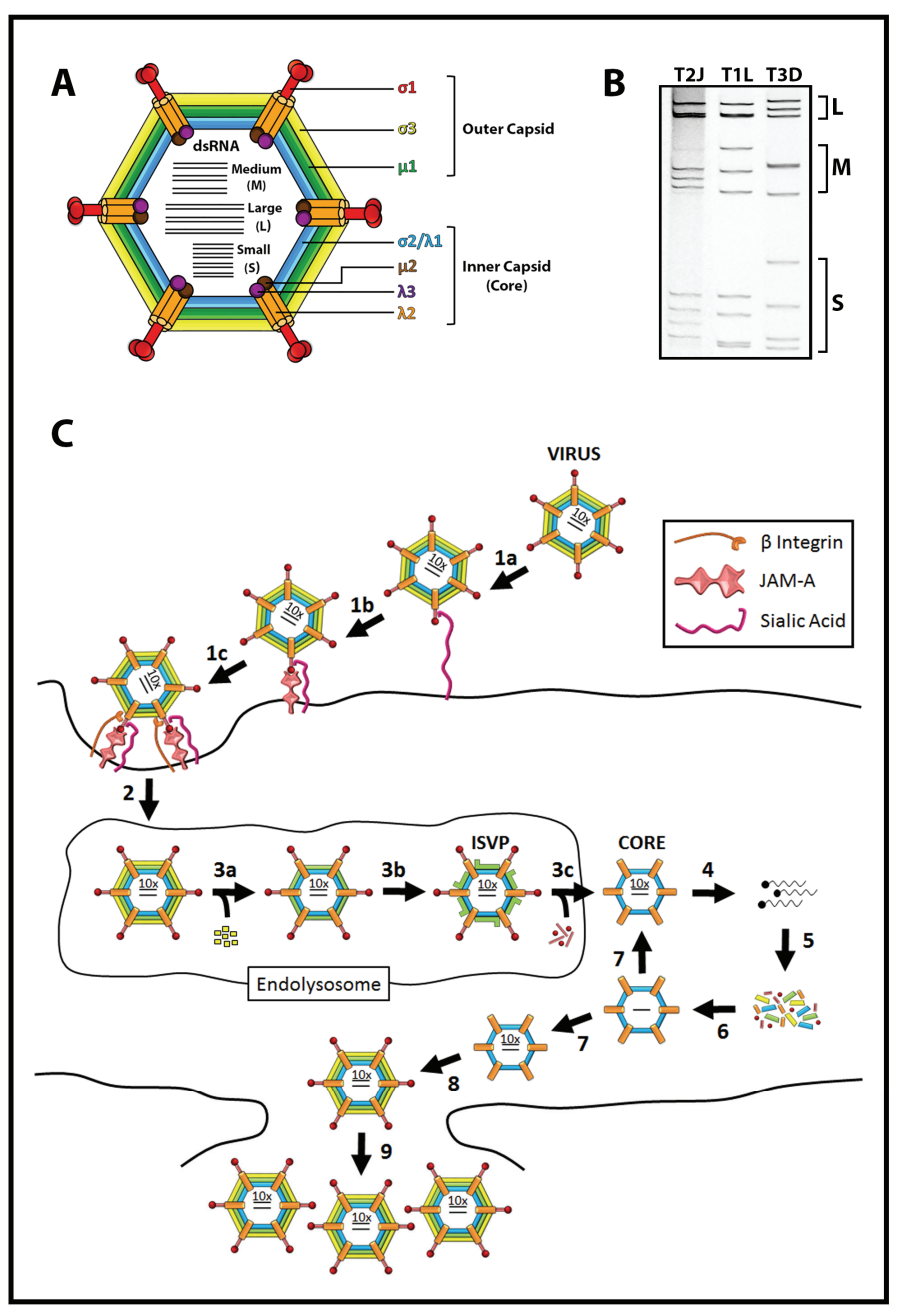

Figure 1. Reovirus structure and replication. (A) Reovirus outer capsid and inner capsid proteins; (B) Genomic dsRNA profiles of prototypic reovirus serotypes 1 Lang, 2 Jones, and 3 Dearing; (C) Life cycle of reovirus. Cell attachment is mediated through (1a) sialic acid binding, (1b) JAM-A association, and (1c) integrin binding; (2) Reovirus is internalized through endocytosis. Within late endosomes/lysosomes; (3) uncoating proceeds through (3a) proteolytic-mediated removal of $\sigma 3$, (3b) cleavage of $\mu 1$ to $\delta$, and (3c) loss of $\sigma 1$ concomitant with membrane penetration and transition to cores; (4) Viral +sense RNAs are transcribed and released by cytoplasmic core particles; (5) Reovirus proteins are expressed and (6) assemble with +sense RNAs into progeny core particles; (7) Genomic dsRNA is synthesized within progeny cores, which serve to amplify reovirus macromolecular synthesis; (8) Reovirus is fully assembled through addition of outer-capsid proteins and released from cells by lysis and/or apoptosis.

Reovirus has a very complex capsid shell composed of 6 structural proteins $(\sigma 1, \sigma 2, \sigma 3, \mu 1, \lambda 1, \lambda 2)$ that interlock into two concentric layers; the inner- and outer-capsids (Figure 1). The RNA-dependent 
RNA polymerase $(\lambda 3)$ and the multifunctional $\mu 2$ protein are packaged inside the virion at each of 12 vertices. The complexity of reovirus capsids likely contributes to stability under harsh environmental and enteric conditions. Reovirus enteric infection involves proteolytic processing of the virion by enzymes in the intestinal lumen. Chymotrypsin and trypsin completely degrade the outer-most protein $\sigma 3$ and cleave the underlying $\mu 1$ protein into membrane-penetrating fragments. The resulting intermediate virions, called infectious subviral particles (ISVPs), can penetrate both surface- and endocytic-membranes. The observation that freshly made ISVPs are more infectious than whole virions supports the evolutionary compatibility of reovirus towards the enteric niche $[2,19]$. Unlike other virus families, reovirus does not fully disassemble. Instead, ISVPs convert into core particles composed of the inner-capsid proteins and dsRNA genome. The core proteins serve to conceal genomic viral dsRNA from the host, which would otherwise stimulate a rapid and potent antiviral response. Reovirus core proteins (polymerase $\lambda 3$, capping enzyme $\lambda 2$ [20], and co-factors $\mu 2$ [21] and $\lambda 1$ [22]) then transcribe and release viral capped mRNAs into the cytoplasm through channels created by pentameric $\lambda 2$ proteins at each vertex. Reovirus proteins are expressed by the host translation machinery, and assemble into progeny cores that further amplify replication (Figure 1). Ultimately, outer capsid proteins are assembled onto cores to produce complete virions, which are released into the intestinal lumen for transmission. The ability of reovirus to bind multiple receptors on unique intestinal cells and to use intestinal enzymes for defined disassembly provide noteworthy examples of how reovirus is intimately adapted for intestinal infections.

\subsection{Reovirus Is a Promising Cancer Therapy}

The use of viruses to treat cancer was suggested a century ago when cancer patients occasionally went into remission following natural virus infection or vaccination [23]. Several viruses including reovirus, vaccinia virus, Newcastle disease virus, adenovirus, Maraba virus and vesicular stomatitis virus demonstrate tumor-specific cytolysis and are therefore candidate cancer therapies. Most oncolytic viruses show specificity towards cancer cells either because they are non-human-tropic, or because they are attenuated or genetically modified. Interestingly, reovirus naturally infects humans yet is inherently more infectious towards transformed over normal cells $[24,25]$.

Normal mouse fibroblasts become permissive to reovirus infection when first transformed by constitutively active H-Ras [26,27], and provide a well-controlled model system for discovering the molecular basis of reovirus specificity towards transformed cells. Over 18 pathways downstream of Ras promote cell growth by modulating a compendium of cellular processes [28]. A comparison of each step of reovirus replication among Ras- vs. non-transformed cells revealed that (1) lysosomal proteolysis of incoming reovirions is enhanced by Ras-transformation [29,30]; (2) progeny virus particles produced in Ras-transformed cells are more infectious than progeny produced in non-transformed cells [29]; (3) Ras-transformed cells are more susceptible to reovirus-induced apoptosis [29,31]; and (4) Ras-transformed cells exhibit impaired IFN expression, thereby permitting efficient cell-to-cell spread of reovirus $[32,33]$. These studies reveal that cellular changes induced by activated Ras signaling create multiple Achilles heels that are ultimately exploited by reovirus for efficient replication. The existence of multiple barriers helps ensure that reovirus replication is strongly tumor-specific. With regards to engineering improved reovirus variants, one should ensure that these four mechanisms of specificity are not jeopardized.

Wild type reovirus demonstrated promising anti-tumor activity in a large assortment of pre-clinical mouse tumor models [34-38]. A Canadian-based biotechnology company, Oncolytics Biotech Inc. (Calgary, AB, Canada), has initiated human clinical trials using wild-type reovirus under the trade-name Reolysin ${ }^{\circledR}$. Twenty-six phase I/II clinical trials have since been conducted, some ongoing, in an assortment of cancers. Reovirus was found to be well tolerated following both intratumoral and intravenous administration, and show preliminary evidence of anti-tumor activity in patients [39-46]. A phase III clinical trial in head and neck squamous cell carcinoma was recently completed [47]. 


\subsection{Optimizing Reovirus Oncolysis}

Despite promising suggestions of antitumor activity, response to reovirus monotherapy in mouse models of aggressive cancers and in human trials of advanced malignancies are described as modest and short-lived [39-46]. On one hand, it is not surprising that phase I and II trials show incomplete response, given the severity of disease among patients in such trials. Conversely, these findings support that advancements to reovirus oncolysis might improve efficacy. Important to this review, all trials currently use the P.W.Lee laboratory strain of reovirus serotype 3 Dearing (T3D) as the wild-type form (T3wt). T3wt provides a practical strategy for proof-of-concept and to obtain FDA approval, as wild-type reovirus is well characterized as non-pathogenic and provides some clinical benefit when used in combination therapy. However, considering that reovirus is exquisitely well adapted for its natural gastrointestinal niche, it seems logical that modifications to reovirus could promote adaptation and potency in the new human-imposed therapeutic cancer niche. Accordingly, development of "next-generation" reovirus variants that exhibit enhanced replication in tumor cells, especially in combination with complementary strategies that reduce immune-clearance and boost anti-tumor immunity, are likely to promote the success of reovirus oncotherapy.

Many studies have demonstrated the benefit of combining reovirus with conventional therapies such as radiation and chemotherapy [41,42,48-50]. Checkpoint blockade is a promising immunotherapeutic strategy that enhances anti-tumor immunity and was recently observed to strikingly improve reovirus efficacy in a pre-clinical mouse tumor model [51]. A long-standing belief by researchers is that combination of multiple cancer-targeting viruses, likely in tandem, would help overcome immune-clearance of individual viruses and harness the combined anti-tumor activities of each virus. This review strives to provide a comprehensive analysis of strategies to modify reovirus itself for improved oncolytic potency and safety. Ultimately, optimal viral oncotherapy will likely incorporate both changes to the virus and combination with other therapeutic approaches.

\section{Cell Attachment}

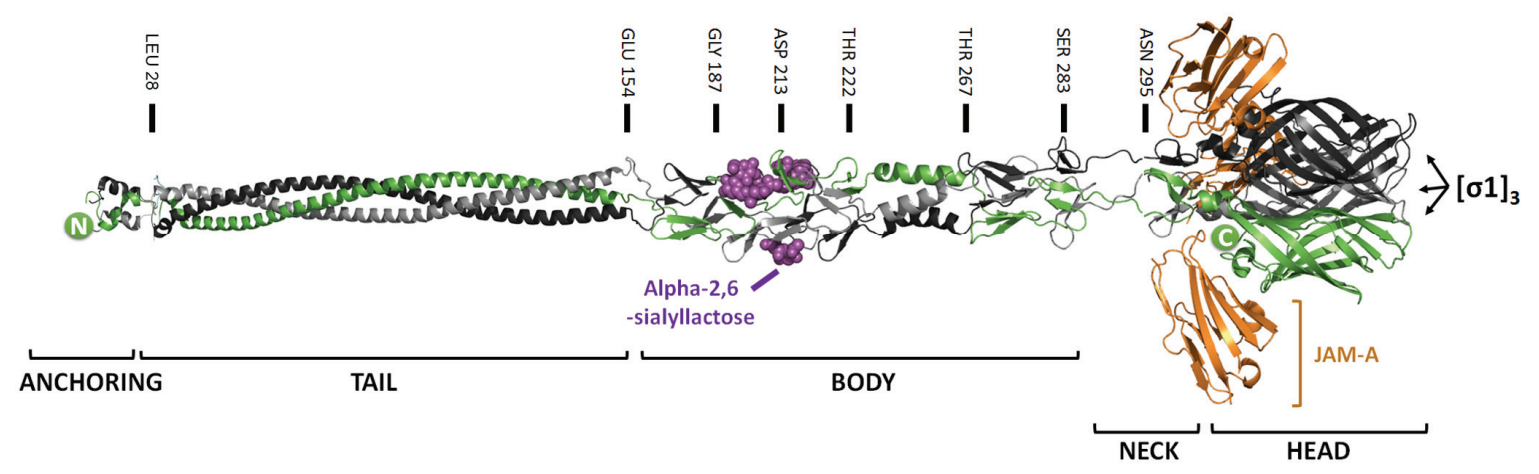

Figure 2. Structure and function of distinct domains in reovirus $\sigma 1$ trimers. Trimers of $\sigma 1$, with monomers colored green, grey, and black. Positions of amino acids that define distinct structural domains are provided. Predicted structure of the N-terminal virion-anchoring domain (residues 1-27) and coiled-coil $\sigma 1$ (residues 27-154) are depicted (coiled-coil crystal structures from the unrelated trimeric autotransporter adhesins, PDB 2YO3, were used for depiction) [52]. The body domain of T3D $\sigma 1$ (residues 154-283) bound to $\alpha$-2-6-sialyllactose (purple) and the neck domain (residues 283-295) are depicted from crystal structure PDB 3S6Y [53]. The C-terminal head domain in complex with JAM-A (orange) are from PDB 3EOY [54]. N- and C-termini are indicated by green circles.

Attachment of reovirus to cells is mediated through at least three distinct interactions between virus and host cells. Trimeric $\sigma 1$ cell attachment proteins protrude from reovirus particle vertices, held in place by interactions between the $\mathrm{N}$-terminal anchoring domain of $\sigma 1$ and the pentameric $\lambda 2$ 
channel proteins. Intrinsic oligomerization of $\sigma 1$ is mediated through a coiled-coil heptad repeat domain referred to as the reovirus tail domain (Figure 2) [55,56]. The body and neck domains, composed of $\beta$-sheet- $\alpha$-helix- $\beta$-sheet structures, are responsible for binding to sialic acid [57]. The neck domain is also subject to proteolysis in some isolates of T3D [58]. The globular head domain mediates interactions with the cellular tight junction associated protein, junction adhesion molecule-A (JAM-A) $[18,59,60]$. Recently it was found that $\sigma 1$ head can also bind to Nogo receptor $\mathrm{NgR} 1$ on neuronal cells [61]. Finally, the extra-virion domain of $\lambda 2$ binds $\beta 1$ integrins to permit firm adhesion and initiate endocytosis-mediated uptake into cells [62,63].

\subsection{Mutations that Modulate Sialic Acid Binding}

Binding of $\sigma 1$ to sialic acids is thought to mediate initial reovirus adhesion to target cells $[57,64]$. The body domain of reovirus T3D binds a range of sialylated glycans such as sialoglycophorin and sialosides with terminal N-acetylneuroaminic acid (NeuNAc) linked in either an $\alpha-2,3$ or $\alpha-2,6$ configuration [57,65-67]. Specifically, amino acids at positions 198, 202 and 204 are implicated in binding of T3D $\sigma 1$ to sialic acids, since mutation of these residues (N198D, R202W, and P204L) eliminates reovirus-sialic acid interactions [68]. In contrast, T1L binds exclusively to GM2 sialylated glycans, and this binding is mediated through the $\sigma 1$ neck domain $[53,65,69,70]$.

To assess the contribution of sialic acid binding for reovirus replication in vitro and in vivo, Dr. Terence Dermody's laboratory (Vanderbilt University) made use of a serotype 3 field isolate (T3C44, also called $\mathrm{T}^{2} \mathrm{SA}^{-}$) that is deficient in sialic acid binding. Using serial passage in MEL cells, which only support replication of sialic acid-binding reovirus strains, the laboratory isolated an isogenic T3C44 variant (T3C44-MA, also called $\mathrm{T}^{2} \mathrm{SA}^{+}$) that gained sialic acid binding through a L204P mutation in $\sigma 1$ (Table 1) [57]. Similarly, sialic acid-binding $\left(\mathrm{SA}^{+}\right)$vs. non-binding $\left(\mathrm{SA}^{-}\right)$ isogenic pairs were created by introducing an R202W point mutation into wild-type serotype 3 Dearing strain (T3D). Both $\mathrm{T} \mathrm{SA}^{+}$and $\mathrm{T}^{3} \mathrm{SA}^{-}$replicated equally well on L cells, which support sialic-acid independent entry, but $\mathrm{T} \mathrm{SA}^{+}$replicated considerably better in HeLa cells relative to $\mathrm{T}_{3} \mathrm{SA}^{-}$. $\mathrm{T}_{3} \mathrm{SA}^{+}$and $\mathrm{T}_{3} \mathrm{SA}^{-}$variants were then compared in a neonatal immunocompromised mouse model, where reovirus infection can spread to the brain, heart and liver and exhibit pathogenesis. T3SA $^{-}$showed altered cell tropism, decreased virus dissemination, and reduced pathogenesis relative to $\mathrm{T} \mathrm{SA}^{+}[61,71,72]$. These studies demonstrate that loss of sialic acid binding can negatively impact reovirus infectivity, though the impact in various tumor models remains to be tested.

Sialic acid binding most likely also plays an important role during reovirus infection of tumor cells, though this has yet to be tested directly. Hypersialylation and incorporation of dietary non-human sialic acid Neu5Gc are common among tumor cells and implicated in tumor growth and immune escape $[73,74]$. Hypothetically, improving the strength of sialic acid binding or sialylated glycan specificity, for example by modifying the T3 sialic acid binding domain or combining the distinct SA binding domains of T1 and T3 serotypes, could further promote specificity and potency of reovirus oncolysis.

Through persistent infection of Vero monkey kidney cells with T3D, Sandekian and Lemay (2015) isolated a reovirus variant (VeroAV) that may provide advantage at the sialic acid binding stage of reovirus infection. VeroAV contains unique mutations in the coiled-coil tail (Q78P) and sialic acid binding (N198K) domains of $\sigma 1[75,76]$. Interestingly, these mutations in $\sigma 1$ were found to improve reovirus infectivity towards Vero cells, especially when combined with co-adapted mutations in the $\mu 1$ outer capsid protein. Binding of VeroAV to Vero cells was stronger than wild-type reovirus and was sensitive to neuraminidase treatment. In the future, hemagglutination assays, surface plasmon resonance, or glycan arrays could be used to directly examine if the N198K mutation promotes enhanced sialic acid binding strength and/or specificity. If sialic acid binding is found to be superior for VeroAV, it would be interesting to determine if this variant replicates better than wild-type reovirus on HeLa and MEL cells (which poorly support T3SA ${ }^{-}$viruses) and especially, on a panel of cancer cells that differ in availability of attachment factors (sialic acids, JAM-A, and integrins). 
Table 1. Reovirus variants with altered infectivity.

\begin{tabular}{|c|c|c|c|c|c|}
\hline & Step & Variant Name & $\begin{array}{c}\text { Mutations } \\
\text { (Amino Acid Change) }{ }^{1}\end{array}$ & Domain Function & Phenotype \\
\hline \multirow{11}{*}{ Improving Potency } & \multirow{6}{*}{ Attachment } & $\mathrm{T} \mathrm{DSA}^{-}$ & $\sigma 1(\mathrm{R} 202 \mathrm{~W})$ & Sialic-binding & $\begin{array}{l}\text { Reduced infection in some cells (e.g., HeLa) and in vivo } \\
\text { pathogenesis in neonatal immunocompromised mice }\end{array}$ \\
\hline & & VeroAV & $\begin{array}{l}\sigma 1 \text { (Q78P; N198K) } \\
\mu 1 \text { (E89G; A114V) }\end{array}$ & Trimerization; Sialic-binding & Enhanced binding to Vero Cells \\
\hline & & Jin-1 & o1 (T193M; Q336R) & Sialic-binding; JAM-A binding & \multirow{3}{*}{ Infectious towards JAM-A deficient cells } \\
\hline & & Jin-2 & o1 (G187R; Q336R) & Sialic-binding; JAM-A binding & \\
\hline & & Jin-3 & $\sigma 1(\mathrm{G} 196 \mathrm{R})$ & Sialic-binding & \\
\hline & & T3D-S1His & $\begin{array}{l}\sigma 1\left((\mathrm{His})_{6} \operatorname{tag} @\right. \\
\text { C-terminus })\end{array}$ & Additional binding domain added & $\begin{array}{l}\text { Ability to replicate in JAM-A-deficient U118 cells that } \\
\text { express (His) }{ }_{6} \text {-specific antibody fragment }\end{array}$ \\
\hline & \multirow{5}{*}{$\begin{array}{l}\text { Uncoating and } \\
\text { Onset of Infection }\end{array}$} & NA & $\begin{array}{l}\mu 1 \text { (A305L), (A276V), } \\
(\mathrm{D} 371 \mathrm{~N}),(\mathrm{Q} 456 \mathrm{R}), \\
(\mathrm{P} 497 \mathrm{~S}),(\mathrm{L} 185 \mathrm{~S}), \text { or } \\
\text { (E89Q) }\end{array}$ & $\mu 1-\mu 1$ interactions & Altered rates of ISVP $\rightarrow$ ISVP* and core production \\
\hline & & $\mathrm{Y} 354 \mathrm{H}$ & $\sigma 3(\mathrm{Y} 354 \mathrm{H})$ & C-terminal surface exposed domain & $\begin{array}{l}\text { Enhanced disassembly and resistance to E64 protease } \\
\text { inhibitor. Enhanced replication, dissemination and } \\
\text { pathogenesis in immunocompromised mice }\end{array}$ \\
\hline & & T3v1 & $\lambda 1$ (N138D) & Inner face of virion core & \\
\hline & & & $\lambda 2$ (M1101I) & Flap domain that open/close & Enhanced particle infectivity and oncolytic activity \\
\hline & & T2? & $\lambda 3$ (P400S) & Core-facing surface & in vivo \\
\hline \multirow{7}{*}{$\begin{array}{l}\text { Improving } \\
\text { Specificity/Safety }\end{array}$} & Attachment & $\begin{array}{l}\text { HTR1 } \\
(\text { AV-Reo) }\end{array}$ & $\begin{array}{l}\text { o1 (J181) } \\
\text { Q251STOP; V127A; } \\
\text { o3 (S177F; H251L) }\end{array}$ & Trimerization; JAM-A binding & Reduced toxicity in vivo \\
\hline & \multirow{6}{*}{ Antiviral Response } & \multirow{3}{*}{ P4L-12 } & o3 (G198E; M221I) & & \multirow{3}{*}{$\begin{array}{l}\text { Increased IFN-sensitivity. Improved specificity towards } \\
\text { IFN-deficient Ras-transformed cells }\end{array}$} \\
\hline & & & $\mu 1$ (P315S; T449A) & & \\
\hline & & & $\lambda 2(\mathrm{~T} 636 \mathrm{M})$ & Methyltransferase domain & \\
\hline & & NA & $\mu 2$ (P208) & Unknown & Important in repression of interferon signaling \\
\hline & & NA & $\begin{array}{l}\text { O3 (R236), (R239), (K291), } \\
\text { or (K293) }\end{array}$ & dsRNA binding domain & \\
\hline & & ts453 & $\sigma 3(\mathrm{~N} 16 \mathrm{~K})$ & $\mu 1$ association domain & Increased dsRNA binding and IFN resistance \\
\hline
\end{tabular}

${ }^{1}$ Mutated residues in bold underline are suggested to play a dominant role in the variant phenotype. 


\subsection{Modifications that Alter Binding to JAM-A or Promote JAM-A Independent Attachment}

Following low-affinity reovirus $\sigma 1$ adhesion to sialic acids, high-affinity binding is attained by binding of the globular $\sigma 1$ head domain to JAM-A (also called JAM-1 or F11). JAM-A is a cell adhesion molecule with diverse functions such as tight junction formation, leukocyte migration and platelet activation [77].

Many studies have found that JAM-A expression is common in cancers and contributes to proliferation, metastasis, and poor prognosis [78-84]. For example, $82 \%$ of cancers covering a wide range of origins stain positive for JAM-A expression according to the Human Protein Atlas (HPA) [85-89]. Terasawa et al. found that among 19 tumor cell lines, 18 were positive for JAM-A expression and that JAM-A did not correlate with differential susceptibility of these cells to reovirus-induced cell death [90]. However, some cancers do show limited accessibility to JAM-A, which would pose a restriction to reovirus oncolysis. For example, van Houdt et al. (2008) found that patient-derived colorectal and liver metastases have cytoplasmic retention of JAM-A using tissue microarrays [91]. Among the cancers evaluated in the HPA, gliomas and melanomas seemed to express relatively limited JAM-A. Accordingly, reovirus variants that can attach to cells in a JAM-A-independent manner could provide improved therapies towards JAM-A-deficient cancers.

Using forward genetics, van den Wollenberg et al. (2012) isolated three reovirus variants that can replicate on JAM-A negative U118 human glioblastoma cells [92]. All three JAM-A independent (jin) variants had mutations proximal to the sialic acid binding motif of the $\sigma 1$ cell attachment protein (T193M, G187R, and G196R in jin-1, jin-2, and jin-3 respectively, Table 1). Variants jin-1 and jin-2 also shared a common secondary mutation, Q336R, in the JAM-A binding domain of $\sigma 1$. Jin-1 was capable of infecting a panel of cancer cells that resist wild-type reovirus infection. Conversely, plaques formed by jin-1 and jin-2 mutants were actually smaller than T3wt on JAM-A expressing human embryonic retinoblast 911 cell line, suggesting that benefits of jin-associated mutations are cell-specific. It would be interesting to evaluate expression of JAM-A and other junction adhesion molecules on the cell panel used in this study, and determine if a reciprocal correlation exists between JAM-A expression and fitness of jin-over wild-type reovirus. Importantly, the jin mutants did not replicate in primary human fibroblasts, demonstrating retained specificity towards tumor cells. Infection by jin mutants was sialic-acid dependent, as treatment with wheat germ agglutinin to occlude sialic acid binding decreased infectivity. It will be necessary to perform attachment assays to directly implicate increased cell binding as the advantage for jin mutants, as these mutations could provide un-anticipated benefits for other stages of reovirus entry and infection. If binding is the basis for enhanced infectivity, it is possible that jin mutants use an auxiliary receptor, that the modifications increase sialic acid affinity, or that the changes reduce virion-cell distance to permit enhanced binding between $\lambda 2$ and integrins.

An alternative strategy to facilitate high-avidity binding of reovirus to JAM-A-deficient cancer cells would be to introduce extrinsic receptor binding domains into $\sigma 1$. The strategy of re-engineering virus cell-attachment proteins (transductional targeting) has worked well for oncolytic adenovirus to overcome limited expression of its receptor, coxsackievirus and adenovirus receptor (CAR), on tumor cells. In fact, since the adenovirus fiber and reovirus $\sigma 1$ cell-attachment proteins show structural similarity, the JAM-A binding head domain of reovirus was successfully fused to the adenovirus fiber tail to re-target adenovirus [93-97]. As a proof-of-concept for feasibility of transductional re-targeting in reovirus, van den Wollenberg (2008) added a hexahistidine (His) tag to the C-terminus of $\sigma 1$ [98], and then expressed a single-chain His-tag-specific antibody fragment on the surface of JAM-A-deficient U118 glioblastoma cells. Strikingly, U118 cells became permissive to reovirus when alternative adhesion mechanisms were provided. As discussed in a section that follows, the advent of an efficient reverse genetics system for reovirus will likely permit additional ingenuity with respect to transductional re-targeting for JAM-A deficient cancers. 


\section{Virus Disassembly, Membrane Penetration, and Establishment of Infection}

\subsection{Reovirus Uncoating Contributes to Specificity and Potency of Oncolysis}

Within minutes of oral ingestion, reovirus exploits the intestinal proteases trypsin and chymotrypsin to cleave outer capsid proteins and undergo structural changes that ultimately permit membrane penetration, production of transcriptionally active core particles, and onset of viral macromolecular synthesis (Figure 1) $[99,100]$. The first intermediates produced during reovirus uncoating are infectious subvirion particles (ISVPs), and requires the complete degradation of outer-most capsid protein $\sigma 3$ and cleavage of the under-lying $\mu 1$ protein [101]. In ISVPs, the myristoylated $\mu 1 \mathrm{~N}$ fragment (residues 1-2), the $\delta$ fragment (residues 43-581) and the short C-terminal $\phi$ fragment remain particle-associated. Host membrane exposure promotes formation of ISVP* through conformational changes in $\mu 1$ and release of membrane-pore-forming $\mu 1 \mathrm{~N}$ and $\phi$ fragments from virus particles [102-111]. The importance of releasing the myristoylated $\mu 1 \mathrm{~N}$ fragment and ISVP* formation is demonstrated by the dramatic loss of infectivity by reovirus particles with mutations that prevent $\mu 1$ processing [104,107]. Finally, membrane penetration liberates remaining outer-capsid proteins $\delta$ and $\sigma 1$ from virions [107], concomitant with opening of the $\lambda 2$ channels at each vertex through which newly synthesized viral RNAs are extruded into the cell cytoplasm to establish infection. The complex steps of reovirus uncoating have been extensively studied and are reviewed thoroughly elsewhere [112,113].

In the absence of intestinal proteases, such as during infection of cells in culture, disassembly of reovirus requires endocytosis and proteolysis by lysosomal cysteine proteases cathepsin B and L $[90,114,115]$. In mice models where reovirus causes pathogenesis, knock-out of cathepsins or use of cathepsin inhibitors affected viral spread among organs and mouse survival [116], indicating that non-intestinal proteases can affect reovirus infectivity in vivo. Furthermore, proteases such as airway trypsin-like protease (HAT) on respiratory cells, neutrophil elastase, cathepsin S, neutrophil cathepsin $G$, and mast cell chymase available during inflammation by infiltrating immune cells can facilitate reovirus uncoating and might contribute to ISVP formation in their respective environments [117-119]. However, intestinal proteases have unique cleavage site preferences and are presumably very abundant [120-122], so it is currently unclear whether reovirus disassembly in lysosomes versus extracellularly by non-intestinal proteases are equally efficient especially in vivo. For example, Nygaard et al. (2011) found that despite ISVP production by HAT in vitro, progeny titers from lungs of mice intranasally infected by complete reovirions were significantly lower than titers from ISVP-infected mice, suggesting inefficient virus uncoating in the murine respiratory tract [119]. Interestingly, pre-treatment of mice with lipopolysaccharide or UV-inactivated reovirus to induce inflammation and immune cell-associated proteases increased conversion to ISVPs in bronchoalveolar lavage fluid, assessed by the proportion of viruses that became resistant to E64 broad-spectrum cysteine protease inhibitor. Progeny virus titers were also significantly increased, and correlated with increased numbers of monocytes. These results indicate that the uncoating efficiency of reovirus is dependent not only on the identity and abundance of proteases available at the site of virus replication, but also by proteases introduced by immune cells.

While reovirus uncoating is one of the most-studied steps of reovirus replication, much less is known about the efficiency of this stage within the tumor environment. Early studies into the molecular basis for reovirus specificity towards transformed cells found that addition of RasV12 oncogene by itself was sufficient to increase cleavage of $\mu 1$ to $\delta$ and onset of reovirus infection by 3-4-fold [29]. Furthermore, cancer cells that were less susceptible to reovirus infection, such as U87 and U118 glioma cells, became infected when exposed to ISVPs generated by in vitro proteolysis $[30,123]$. Similarly, tissue fragments and single-cell populations of patient-derived colorectal tumor cells were susceptible to reovirus ISVPs but not whole virions [91]. A comparison of 19 human cancer cell lines found that susceptibility to reovirus infection and cytopathic effect correlated with active levels of cathepsins B and L [90]. Together, these studies demonstrate that 
efficiency of uncoating contributes to reovirus specificity towards tumor cells over non-transformed cells, and that the availability of proteases in cancer cells further modulates the extent of reovirus infectivity.

With respect to tumors in vivo, many extracellular proteases have been found to increase in expression and extracellular distribution. However, it is currently unclear whether extracellular and intracellular proteases produced by tumor and tumor-associated immune cells are of sufficient type and abundance to efficiently uncoat reovirus. Intriguingly, while U118 glioma cells could not support infection by whole virions in cell culture, in vivo subcutaneous tumors derived from U118 cells effectively regressed by a single intratumoral dose of reovirions [30]. Cathepsin B activity in both U118 and U87 glioma cells was notably higher in implanted tumors than cells grown in culture. An independent study found that spheroids derived from U118 cells also became susceptible to reovirus infection and had increased levels of cathepsins [124]. These studies suggest that the tumor microenvironment might support reovirus uncoating even when cells in culture cannot. Further studies are needed among distinct tumors, to fully appreciate the extent to which tumor proteases are sufficient or insufficient for maximal reovirus infectivity, dissemination, and oncolysis.

\subsection{Mutations in $\sigma 3$ Promote Reovirus Uncoating}

Reovirus variants with distinct abilities to accomplish specific steps of uncoating could provide important information on the efficiency of uncoating in tumors, and perhaps provide a tool to promote the potency of reovirus oncolysis. Many distinct mutations have been found to affect reovirus uncoating, though to our knowledge, these reovirus variants have yet to be evaluated relative to wild-type reovirus in tumor models. The outermost outer-capsid protein, $\sigma 3$, is thought to protect the underlying $\mu 1$ protein from prematurely undergoing conformational changes needed for membrane penetration [125]. The initial step of reovirus uncoating therefore requires the degradation of $\sigma 3$. Many studies have revealed the importance of distinct structural domains of $\sigma 3[108,126-129]$. Sigma 3 is composed of a small lobe (Figure 3, resides 1-90 and 287-336, purple) that coordinates zinc binding (resides 51, 54, 71, and 73) and interacts with $\mu 1$. The larger lobe (Figure 3 , residues $91-286$ and 337-365, red) protrudes from the virion and is therefore exposed to proteases. In vitro cleavage by proteases, such as chymotrypsin, trypsin, and cathepsin L, occur within solvent exposed hypersensitive regions, such as resides 211-215 and 238-244 of serotype 3 virions [101,115]. Importantly, the rates of $\sigma 3$ cleavage in serotype 3 reovirus (T3D) could be increased by substitution at C-terminal positions 344, 347, and 353, and to a lesser extent by other residues in positions 1-265 [101]. These findings demonstrate the importance of multiple domains on the efficiency of $\sigma 3$ cleavage.

Several variants of reovirus with distinct mutations in $\sigma 3$ have been found to exhibit increased rates of uncoating $[130,131]$. Most well studied is a T3D reovirus variant selected from persistently infected L929 cell cultures containing a mutation in $\sigma 3$ at position $354(\mathrm{Y} 354 \mathrm{H})$. This variant showed increased rates and efficiencies of $\sigma 3$ degradation and subsequent $\mu 1$ to $\delta$ cleavage during in vitro proteolysis. The $\mathrm{Y} 454 \mathrm{H}$ variant was capable of infecting cells treated with ammonium chloride or pan-cysteine protease inhibitor E64, suggesting it is capable of uncoating in the absence of lysosomal proteases [130,132-134]. The phenotype of $\mathrm{Y} 354 \mathrm{H}$ was reversed by a secondary glycine-to-aspartate change at position 198 in close 3-dimensional proximity (Figure 3) [133]. In the context of immunodeficient mice, the $\mathrm{Y} 354 \mathrm{H}$ variant replicated and disseminated more proficiently than wild-type reovirus after intramuscular or peroral administration, causing increased lethality [135]. As for application to oncolytic therapy, the increased pathogenesis of $\mathrm{Y} 354 \mathrm{H}$ may raise safety concerns in immunosuppressed individuals. However, given the multifaceted specificity of reovirus towards tumors in immunocompetent models and limited toxicity in humans, it is possible that $\mathrm{Y} 354 \mathrm{H}$ would exhibit improved infectivity towards cancer cells that express low cathepsin levels or towards tumors that have fewer extracellular tumor proteases. Furthermore, it was found that mice exposed to the Y $354 \mathrm{H}$ variants had increased levels of cytokines, such as IFN $\beta$, IL-6, and IFN $\gamma$, which could have either positive or negative effects on reovirus oncolysis by either increasing anti-tumor immunity 
or decreasing virus dissemination respectively. It is also noteworthy that $\sigma 3$ has dsRNA binding capacity important for evading detection of viral RNAs by cellular antiviral proteins such as PKR; the effects of mutations to $\sigma 3$ that are aimed towards increasing efficiency of uncoating should therefore be evaluated for potential secondary effects on antiviral signaling $[136,137]$. Ultimately, a side-by-side comparison of $\mathrm{Y} 354 \mathrm{H}$ variant to wild-type reovirus among various immunocompetent tumor models would be highly informative for determining whether enhanced uncoating could enhance oncolytic potency without jeopardizing safety.

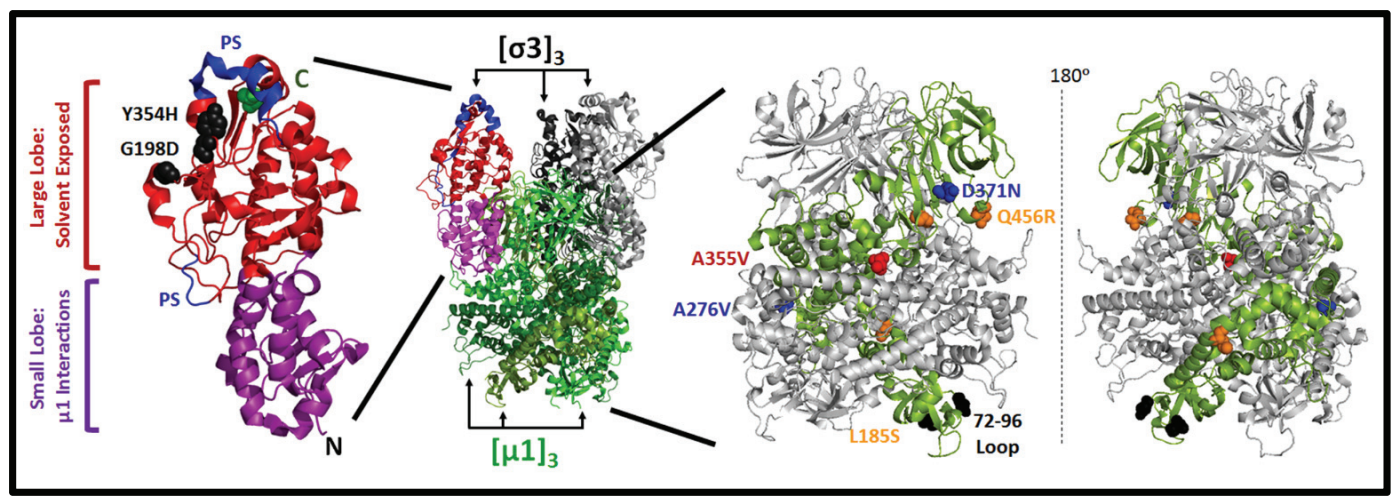

Figure 3. Structural and functional domains of reovirus $\sigma 3$ and $\mu 1$ outer capsid proteins. (Middle) Crystal structure of $\mu 1$ timers (light, medium and dark green) in association with $\sigma 3$ (black, grey, and multi-color) in T1L reovirus (PDB pdb1jmu) [126]; (Left) Domains of $\sigma 3$ from T3D reovirus (PDB 1FN9) are depicted including two protease hypersensitive regions (PS, blue) [128]. Positions of two mutations G198D and Y354H discussed in the text are indicated with black spheres. N- and C-terminus (green sphere) are indicated; (Right) Associations between three $\mu 1$ monomers (one is green, two others are grey) are depicted in mirror-images. The 72-96 loop (black), and mutations that lie between $\mu 1$ trimers (blue) or between $\mu 1$ monomers (orange), discussed in the text, are highlighted with spheres.

\subsection{Mutations in $\mu 1$ Modulate Reovirus Uncoating}

As anticipated, the rate and efficiency of uncoating is also modulated by sequence and structure of $\mu 1$ (Figure 3). Reovirus serotypes 1 vs. 3 exhibit different efficiencies of ISVP-to-ISVP* conversion associated with a polymorphisms in $\mu 1$, specifically at position $305[106,109,138]$. Sarkar and Danthi (2013) sought to further explore the role of a loop at residues $72-96$ of $\mu 1$ during reovirus uncoating, since the loop mediates both $\mu 1-\mu 1$ interactions and associations between $\mu 1$ and the virion core proteins $\sigma 2$ and $\lambda 1$ [139]. Mutations at position 89 from glutamic acid to alanine (E89A) or glutamine (E89Q) enhanced the capacity for transition from ISVP to ISVP*. Surprisingly, this mutation concomitantly rendered virions less (rather than more) infectious. These findings stress the importance of orchestrated uncoating, and that merely making virions less stable is not necessarily favorable. The authors then isolated reovirus variants that reverted to wild-type phenotype. Mutations at residues that lie between $\mu 1$ trimers (A276V, D371N) or between $\mu 1$ monomers (Q456R, P497S, L185S) were capable of restoring wild-type ISVP-to-ISVP* conversion. Relevant to the quest for improved reovirus potency, when the L185S, A276V, D371N, and Q456R reversion mutations were present alone (i.e., in the absence of the $\mathrm{E} 89 \mathrm{Q}$ or $\mathrm{E} 89 \mathrm{~A}$ mutation), plaques were equal or larger than wild-type reovirus. It would be interesting to determine if these mutations promote plaque size and reovirus replication in cancer cells.

\subsection{Reduced Virion-Associated o1 Promotes Reovirus Oncolysis}

Following membrane penetration, reovirus particles must fully uncoat into core particles to initiate transcription, protein translation, and new virion production. In a search for mutations 
that promote reovirus oncolysis, Shmulevitz et al. (2012) isolated two variants of the P.W.Lee T3D laboratory strain, T3v1 and T3v2, that had 3-4-fold higher infectivity-per-particle than wild-type reovirus toward a panel of cancer cells [140]. Though only a marginal increase, T3v1 and T3v2 showed exponentially compounding infection over daily round of replication in tumorigenic cells. Importantly, both variants maintained their specificity towards transformed cells. In an aggressive immunocompetent murine model of melanoma, both variants significantly increased survival relative to wild-type reovirus. These variants are among the few that advanced to in vivo proof-of-concept testing for the potential to improve reovirus oncolysis through mutations that promote virus replication. T3v2 contained a single mutation in the domain of $\sigma 1$ involved in anchoring $\sigma 1$ trimers in virions (S18I). The key phenotype-conferring mutation in T3v1 was in the extra-virion flap domain of $\lambda 2$ (M1101I), which was previously found to transition from closed-to-open conformation during ISVP*-to-core formation and release of $\sigma 1[107,108,141-146]$. T3v1 also had mutations in the RNA-dependent RNA polymerase $\lambda 3$ and the inner core protein $\lambda 1$, though the relevance of these mutations remains to be tested. The improved oncolytic activity of T3v1 and T3v2 was attributed to decreased levels of $\sigma 1$ cell attachment proteins on incoming virions, and consequently more-efficient production of reovirus cores with un-occluded $\lambda 2$ vertex, higher yields of viral RNA, and increased onset of productive infection [147]. In further support for the benefit of reduced $\sigma 1$ on reovirions, increased infectivity could also be attained by reducing $\sigma 1$ levels on T3wt using RNA interference during virion production. It should be noted that previous analysis by Larson et al. (1994) found only a modest difference in pfu/virion with decreasing virion $\sigma 1$ levels, and concluded that $\sigma 1$ levels do not influence infectivity [148]. A discrepancy between the Shmulevitz et al. (2012) and Larson et al. (1994) findings might reflect differences in the laboratory strain used or differences in assay sensitivities and interpretations. These studies suggest that in the context of the P.W.Lee T3D laboratory strain, 3-5 $\sigma 1$ trimers are optimal for reovirus infectivity towards tumor cells.

\section{Macromolecular Synthesis, Progeny Virus Production and Virus Release}

Upon accessing the cytoplasm, the conformationally-rearranged cores become transcriptionally active.

Packaged within the cores are the reovirus RNA-dependent-RNA polymerase $\lambda 3$ and co-factor $\mu 2$ which mediate synthesis of viral RNAs. Viral RNAs are then capped as they exit through the pentameric $\lambda 2$ channels at each core vertex. Reovirus proteins are then synthesized using the host translation machinery. De novo reovirus proteins and positive-sense RNAs assemble into progeny core particles. Double-stranded RNAs are then synthesized within progeny cores and serves as a template for more mRNAs that exponentially amplify reovirus replication. Virion replication and assembly occurs within localized centers called virus factories. Several proteins including structural protein $\mu 2$ and non-structural proteins $\mu \mathrm{NS}$ and $\sigma \mathrm{NS}$ facilitate virus factory formation. Ultimately, reovirus cores are completely assembled by addition of outer capsid proteins $\mu 1$ and $\sigma 3$, and are released from the cell. The time to complete one life cycle of reovirus can vary among cells, but reovirus generally reaches peak titers and release between 18-24 h post-infection of tumorigenic L929, Ras-transformed NIH-3T3 mouse fibroblasts and permissive human cancer cells. This means that a mere four-fold enhancement of any stage of reovirus infection could produce up to $16,000 \times$ more infectious virions through exponential replication and cell-cell spread in a single week.

With regards to mutations that promote these steps, a proline at position 208 of reovirus $\mu 2$, which is already present in serotype 3 but not in serotype 1 reoviruses, is associated with distinct virus factory morphology and improved virus replication. However, there has, remarkably, been no additional mutations, to our knowledge, that promote post-entry steps of $\mathrm{T} 3$ virus replication in permissive cells. It is unclear whether this reflects a lack of research that focuses on promoting post-entry replication steps, or that post-uncoating processes are already optimal in permissive cancer cells. If steps of reovirus replication and release are sub-optimal in the human-imposed tumor niche, then increasing the efficiency of post-entry replication will likely promote yield, dissemination and oncolytic potency of reovirus. 


\section{Improving Reovirus Specificity and Safety}

\subsection{Modifying Reovirus-JAM-A Binding}

The safety of using reovirus during cancer therapy was originally supported by the established non-pathogenic nature of reovirus during natural infections. Nevertheless, both dose and route of administration differs considerable when reovirus is used as a cancer therapy relative to normal environmental virus exposure. Over the past decade, numerous clinical trials have therefore tested the safety of reovirus in clinical trials, and have demonstrated minimal side-effects in reovirus-treated patients. Maximizing therapeutic virus safety will however always remain a worthwhile pursuit.

While exploring the fate of cancer cells that become persistently infected by reovirus, Kim et al. (2007) discovered a reovirus variant that exhibits reduced toxicity in mice models $[149,150]$. Human HT1080 fibrosarcoma cells exposed to reovirus develop clonal populations of virus-resistant cells. Interestingly, reovirus-resistant cells were found to be persistently infected and importantly, to have lost their tumorigenic potential in vivo. The attenuated reovirus (AV-Reo) extracted from HT1080 virus-resistant cells had several mutations in the viral $\sigma 1$ cell attachment protein and $\sigma 3$ outer-capsid protein (Table 1). Most notably, a pre-mature stop codon resulted in truncation of $\sigma 1$ after the sialic-acid binding domain (Figure 2). Given the loss of the JAM-A binding domain in $\sigma 1$, the authors sought to evaluate the oncolytic activity and specificity of AV relative to wild-type reovirus. In vitro, AV-Reo showed similar infectivity and virus protein synthesis relative to T3wt among HT1080 cells, tumorigenic mouse L929 fibroblasts, and HCT116 human colorectal carcinoma cells. However, AV-Reo did exhibit reduced cytopathic effect (CPE) in L929 and HCT116 cells, suggesting that this variant is somewhat attenuated. When injected intra-tumorally into xenografts established from human colorectal HCT116 cells or HT1080 cells, both AV- and wild-type reovirus caused similar and almost-complete reduction in tumor volumes. Remarkably, AV-Reo showed fewer side-effects in vivo relative to wild-type reovirus. For example, AV-reovirus was less cytopathogenic towards normal embryonic stem cells (ESCs) and in vivo teratomas established from ESCs. Whereas wild-type reovirus caused myocarditis in severe combined immunodeficiency (SCID) mice, immunohistochemical analysis found limited staining for AV-reovirus in hearts and no signs of heart tissue damage by hematoxylin and eosin staining. Reovirus-associated black-tail syndrome and animal morbidity was also reduced in AV-reovirus-treated SCID mice. Interestingly, two other reovirus variants that were isolated from distinct persistently-infected cultures of Raji or CA46 cells also had mutations in reovirus $\sigma 1$ and $\sigma 3$ proteins, but retained a full-length $\sigma 1$ cell attachment protein and also exhibited toxicity towards immunosuppressed mice. Together, these studies suggest that reovirus containing $\sigma 1$ devoid of the JAM-A-binding head domain may provide continued anti-tumor activity with improved safety in immunosuppressed patients.

The finding that AV-reovirus showed reduced toxicity in immunocompromised mice is congruent with studies that demonstrated a requirement for JAM-A during hematogenous dissemination of reovirus [151]. Specifically, a strain of serotype 3 reovirus deficient in sialic acid binding [152] (to eliminate confounding effects by sialic acid) was introduced perorally into wild-type (WT) or JAM-A-null newborn C57B mice. Titers of reovirus in the intestine and enteric spread among littermates was similar in JAM-A ${ }^{-/-}$and WT. This finding suggests a JAM-A- and sialic acid-independent mode of entry is possible during enteric infections. Nevertheless, JAM-A was required for dissemination of reovirus to the liver, heart and brain, and for clinical signs of disease and morbidity. The lack of JAM-A toxicity by AV-Reo, may therefore represent a phenotype similar to JAM-A deficient mice. An important question that arises from these studies is whether JAM-A binding is required for dissemination of reovirus to metastatic sites. It would be prudent to determine if AV-Reo can efficiently reach a tumor when injected intravenously, and spread to sites of metastasis. If JAM-A binding is required for spread of reovirus to sites of metastasis, then the benefits of reduced toxicity would have to be carefully weighed against the oncolytic benefits. Alternatively, the JAM-A 
binding head of $\sigma 1$ could be engineered to bind novel tumor-specific target molecules, as discussed elsewhere in this review.

\subsection{Increasing Interferon Sensitivity}

While normal healthy cells are well equipped to detect virus pathogen-associated molecular patterns (PAMPS), produce cytokines such as interferons, and upregulate antiviral proteins that thwart infection, tumor cells often acquire deficiencies in these pathways. Though the mechanisms for reduced antiviral signalling in cancer cells is poorly understood, it is thought to arise from the pressure on tumors to evade immune detection. Like most viruses, reovirus possesses strategies to hamper the antiviral response. For example, while most RNA viruses expose dsRNA replication intermediates in the cytoplasmic that can be detected by PAMP-receptors (e.g., RIG-I, MDA5), reovirus maintains its dsRNA within the core particle at all times. Reovirus transcripts synthesized by viral core particles are capped at the $5^{\prime}$ end by enzymatic activities of viral $\lambda 2$ and co-factor $\mu 2$, which avoids recognition of uncapped $5^{\prime}$ triphosphate RNA by RIG-I. The $\sigma 3$ protein of reovirus binds and sequesters viral RNAs from PAMP-receptor detection [136,153-156]. Finally, reovirus $\mu 2$ alters subcellular localization of interferon regulatory factor 9 (IRF9) needed for expression of interferon-stimulated genes (ISGs) [157,158]. Using reassortant analysis, Sherry et al. (1998) also found a role for viral core proteins $\sigma 2$ and $\lambda 2$ in sensitivity to IFN- $\beta$ [159]. Nevertheless, reovirus remains some-what sensitive to IFNs and ISGs, and differential activation of antiviral signaling is one of several mechanisms for specificity of reovirus towards tumor cells $[29,32,33]$.

Specificity of some oncolytic viruses towards cancers has been improved by inactivating their antiviral evasion mechanism. For example, the $\gamma 34.5$ gene product of herpesvirus- 1 (HSV-1) usurps cellular PP1 $\alpha$ phosphatase to inactivate TBK1 (a kinase involved in antiviral signaling) and to restore activity of eIF $2 \alpha$ required for continued protein translation [160-163]. Removal of $\gamma 34.5$ diminishes neurovirulence of HSV-1 and contributes to oncolytic specificity. The inability of non-human-tropic viruses such as Newcastle disease virus (NDV), vesicular stomatitis virus (VSV), and parvovirus minute virus of mice (MVM) to overcome antiviral response in human cells also contributes to their specificity towards tumors [164-166]. With respect to reovirus, it would be interesting to determine if further debilitation of antiviral evasion strategies would promote tumor-specificity and safety.

Using chemical mutagenesis, Rudd and Lemay (2005) selected reovirus variants with increased sensitivity to interferon and therefore increased specificity towards IFN-deficient transformed cells [33]. Specifically, variants P4L-12 showed $~ 1000$-fold reduced titers in interferon-treated L929 cells relative to wild-type reovirus. In normal NIH3T3 mouse fibroblasts, which are highly proficient at antiviral signalling, there was minimal viral protein expression by P4L-12. In contrast, P4L-12 replicated robustly in Ras-transformed NIH3T3 fibroblasts that have deficient IFN signaling [32]. Genome sequencing of P4L-12 identified mutations in several reovirus genes (Table 1) [75]. To discover which mutation corresponds with increased IFN sensitivity, Sandekian and Lemay (2015) generated recombinant viruses by site-directed mutagenesis and reverse genetics. A threonine-to-methionine change at amino acid position 636 of $\lambda 2$ was sufficient to confer IFN sensitivity. This residue lies in one of two methyltransferase domains of $\lambda 2$, and may therefore contribute to the efficiency of mRNA capping and recognition by cellular proteins that bind $5^{\prime}$ triphosphate RNAs (e.g., RIG-I). Direct evidence for differences in mRNA capping would strengthen this proposed mechanism. Nevertheless, these studies provide proof-of-concept for the possibility of increasing sensitivity of reovirus to antiviral responses and thereby promoting specificity towards IFN-deficient cells. Based on this premise, it is likely also possible that modifications to reovirus $\sigma 3$ and $\mu 2$ could enhance specificity of reovirus by increasing IFN-sensitivity. For example, a proline at position 208 of $\mu 2$ was found to be important for repression of IFN signaling [157]. Basic residues in the carboxyl terminus of $\sigma 3$, such as R236, R239, K291, and K293, were found to be necessary for dsRNA binding [136,167]. It was also demonstrated that interactions between the amino-terminus of $\sigma 3$ and the outer capsid $\mu 1$ protein, which are necessary for reovirus assembly, 
alter the subcellular distribution and dsRNA binding activity of $\sigma 3[167,168]$. A temperature sensitive mutant of reovirus (ts453) with an N16K mutation in $\sigma 3$ that diminishes $\mu 1$ association shows improved interferon resistance [169]. These domains of $\mu 2$ and $\sigma 3$ could potentially be modified to decrease their protective effects against IFN and PKR activation, thereby making reovirus more specific for IFN-deficient cells.

While the rationale for increasing reovirus specificity by modulating virus attachment or IFN sensitivity is logically sound based on in vitro studies, it is critical that these concepts be evaluated in vivo. Since oncolytic activity of reovirus is mediated through both direct virus-killing and indirect promotion of anti-tumor immunity, a comparison of wild-type reovirus-to-reovirus variants that increase antiviral signaling or sensitivity is pivotal in immune-competent cancer models. Such studies would indicate the contribution of IFN activation and sensitivity to anti-tumor responses. Furthermore, while Ras-transformed NIH3T3 cells exhibit undetectable IFN signaling, these cells provide the extreme-case-scenario. Cancer cells differ widely in the extent of their ability to produce or respond to IFNs. Accordingly, it is also important that IFN-sensitive reovirus variants be tested in a panel of human cancer cell xenografts in immune deficient mice, to ensure that reovirus proliferation and potency of direct-killing is not jeopardized.

\section{Reovirus Reverse Engineering and Expression of Exogenous Genes}

Reverse engineering systems for dsRNA viruses such as reovirus lagged behind other RNA and DNA viruses but were finally achieved by several progressive efforts. In 1999, recoating genetics was used to reconstitute wild-type reovirus cores with engineered forms of outer-capsid proteins in vitro [141,170]. In the early 2000s, plasmid-guided in vitro transcribed RNAs were successfully incorporated into infectious reovirions following transfection-infection methods [171-175]. This system demonstrated the feasibility of reverse genetics but was impeded by the need to separate input from recombinant virus. In 2007 came the first completely plasmid-based system for reovirus reverse genetics [176-179]. Each of 10 reovirus genome segments were cloned upstream of a bacteriophage T7 RNA promoter to preserve authentic RNA $5^{\prime}$ ends. The antigenomic hepatitis delta virus ribozyme was used to generate authentic RNA $3^{\prime}$ ends. Evolution of the system from using vaccinia-expressed T7 RNA polymerase, to a T7 RNA polymerase-expressing baby hamster kidney (BHK) cell line, to plasmid-derived T7 polymerase led to increased efficiency of the system; as did convergence of multiple reovirus genome segments into a 4-plasmid system. The reverse genetics plasmids were kindly deposited into the Addgene plasmid repository and are now widely in use. Reovirus reverse genetics now permits rationale design of reovirus variants with improved oncolytic activity, and importantly, simultaneous incorporation of multiple advantageous modifications within single next-generation oncolytic reovirus platforms.

The ability to express exogenous proteins from reovirus has advanced alongside the reverse genetics systems and most recently has become possible. First, reovirus S2 and S4 genes were replaced by either chloramphenicol transferase or GFP, respectively [171,177]. Replication of these recombinant reoviruses required trans-expression of the authentic reovirus proteins $\sigma 2$ or $\sigma 3$, making these vectors less practical as oncolytic therapies. Demidenko et al. (2013) generated reovirus vectors that express over 300 amino acids of exogenous protein sequence [180]. Their vectors focused on inserting exogenous polypeptides into either the $3^{\prime}$ or $5^{\prime}$ ends of reovirus segments S3, M1, or L1 (Figure 4). In-frame tandem duplication of $3^{\prime}$ or $5^{\prime}$ sequences ensured maintenance of cis-acting signals for RNA packaging, transcription and translation. To prevent recombination and reversion to wild-type sequences, wobble-positions of the inner repeat were mutagenized while conserving amino acid sequence. The 2A-like CHYSEL (cis-acting hydrolase element) element from Thosea asigna virus was used to express a both the exogenous peptide and authentic reovirus protein via ribosome skipping. Interestingly, reduction of RNA secondary structure by wobble-mutagenesis was important for increasing the size-allowance of inserts. Using this approach, recombinant reoviruses expressing simian immunodeficiency virus Gag polypeptides were generated. Gag-expressing reovirus could 
illicit a strong antigen-specific splenic $\mathrm{CD} 8^{+} \mathrm{IFN} \gamma^{+} \mathrm{T}$-cell response in mice. In the context of oncolysis, similar strategies could be applied to introduce exogenous genes that increase the oncolytic potency of reovirus. For oncolytic purposes, however, it would be important to ensure that exogenous gene expression does not impinge unfavorably on the efficiency of reovirus replication in tumors.

As mentioned above, it was previously demonstrated that truncated $\sigma 1$ with retained sialic acid binding capacity but no JAM-A binding head domain is sufficient for reovirus infectivity in some cancer cells and potentially a safer alternative due to reduced toxicity towards healthy stem cells [92,149]. van den Wollenberg et al. therefore replaced the $\sim 25 \mathrm{kDa}$ head domain of $\sigma 1$ with a porcine teschovirus-1 2A-like CHYSEL element followed by the small green fluorescent protein iLOV [181]. Recombinant iLOV-Reovirus caused equal-or-more infectivity and cell killing in JAM-A-deficient cells. Future single- and multi-step growth curve analysis in a variety of cancer cells, in addition comparisons in an in vivo tumor model, will aid in appreciating the relative fitness of wild-type vs. iLOV-reovirus. The authors also indicate that loss of iLOV was seen during repeated virus propagation and rapid-quenching of the iLOV fluorophore; hurdles that will undoubtedly be overcome. In the future, additional small binding motifs could also be added to enhance virus binding affinity and specificity beyond sialic acid recognition.

\section{A. Reverse Genetics Backbone by Kobayashi et al. (2007)}

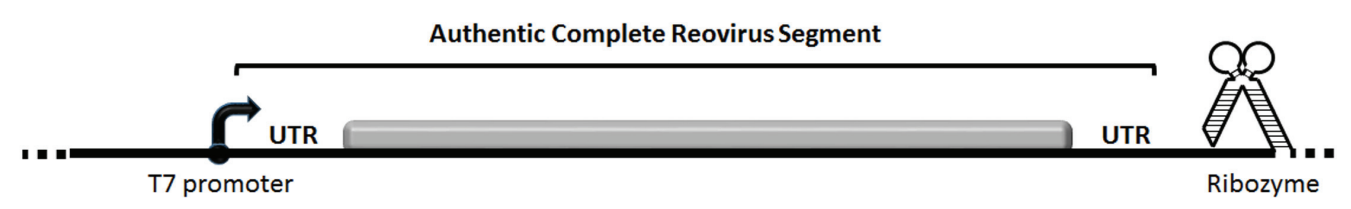

\section{B. Recombinant Reovirus by Demidenko et al. (2013)}

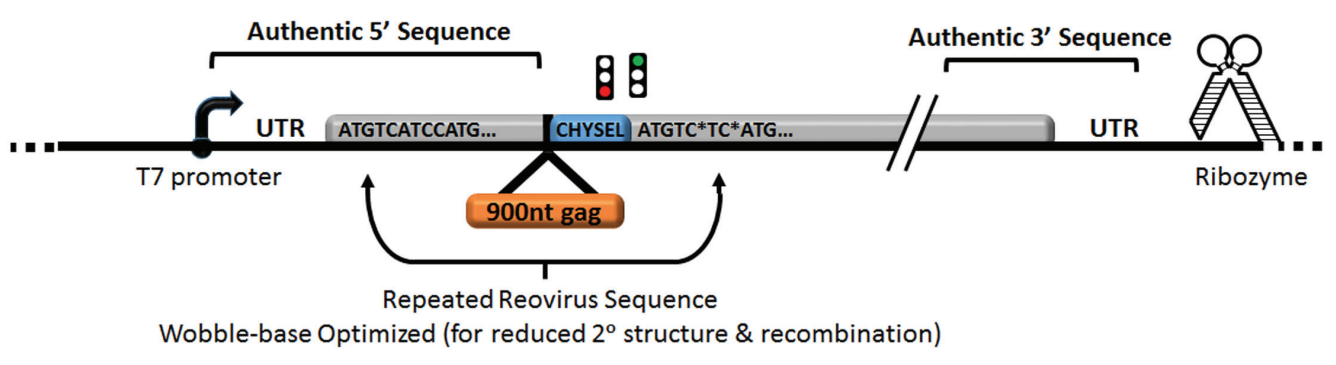

C. Recombinant Reovirus by van den Wollenberg et al. (2015)

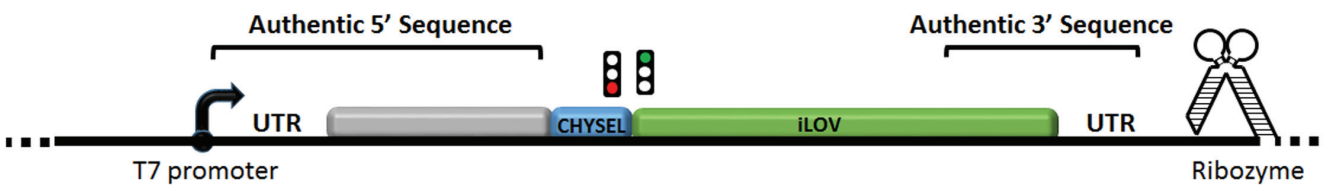

Figure 4. Recombinant reovirus containing exogenous sequences. Illustration of reovirus reverse genetics constructs containing T7 RNA polymerase promoter and ribozyme flanking the $5^{\prime}$ and $3^{\prime}$ UTR respectively. Reovirus gene segment: (A) unmodified, (B) encoding SIV-gag, or (C) encoding iLOV, were generated as described in the text. In (B) wobble base mutations are denoted by asterisk $\left(^{*}\right)$. Constructs were cloned into vector backbone denoted by ellipsis ( . . ).

Several groups have also successfully modified reovirus proteins to alter surface epitopes or binding specificity. The C-terminus of the S1-encoding $\sigma 1$ cell attachment protein was found 
to tolerate a hexahistidine tag or up to three consecutive HA tags (Figure 2 depicts C-terminus of $\sigma 1)[98,182]$. Cell binding and replication of these tagged- $\sigma 1$ virions was moderately impaired and will benefit from future optimization. As previously mentioned, addition of the hexahistidine tag permitted binding to JAM-A-deficient cancer cells that were modified to express a single-chain tag-specific antibody and demonstrate the potential for further engineering of reovirus receptor specificity in the future. Using the in vitro recoating genetics approach, Rouault and Lemay (2003) also incorporated an epitope tag at the $\mathrm{C}$-terminus of the $\mathrm{S4}$-encoding $\sigma 3$ (Figure 3 depicts $\mathrm{C}$-terminus of $\sigma 3)$ [183]. Though modification of $\sigma 3$ decreased virus uncoating efficiency, this strategy could be optimized using plasmid-based reverse genetics to introduce better-tolerated modifications to $\sigma 3$.

The rapid progression of reovirus reverse engineering opens a plethora of possibilities to promote the potency of reovirus oncolysis. Strategies could seek to reduce neutralization by pre-existing antibodies, improve virus binding to JAM-A deficient cancers, optimize the stability-instability balance towards tumor microenvironments, express tumor antigens or cytokines that promote tumor immune responses, or promote bystander tumor cell killing. Such strategies are already in-play for other oncolytic viruses, such as VSV, vaccinia virus, and adenovirus, which are more-easily modifiable and have increased protein coding potential.

\section{Future Directions}

Over the last decade, studies have focused on demonstrating that reovirus holds promise as an oncolytic therapy. With overwhelming evidence that reovirus does exhibit some efficacy and is safe, and with recent advancement of oncolytic viruses towards clinical use, it is now time to focus on bringing reovirus to its ultimate oncolytic potential.

Copious modifications await to be discovered and applied to improve the specificity, safety and potency of oncolytic reovirus. For decades, reovirus provided a safe and powerful tool for mechanistic studies in virology, leading to an abundance of basic research on reovirus structure and replication. Basic discoveries can now help guide well-informed innovations to the reovirus oncolytic vector. One strategy to improve oncolytic reovirus potency would be to improve virus replication and dissemination in the tumors. Given that reovirus evolved for a specialized niche in nature, we believe that adaptation to the human-imposed tumor niche will yield important advancement in oncolytic potency. Improved reovirus infectivity towards tumors would not only increase direct cell-killing, but presumably would increase the indirect benefits of promoting anti-tumor immunity. While this review summarizes many ideas that might improve reovirus replication in tumor cells, it is evident that only few of these ideas have progressed to testing in bona fide tumor models. It should also be noted that genetic and phenotypic differences between laboratory strains of T3D are widely accepted and commonly used as tools to understand reovirus evolution and gene function. More direct head-to-head comparisons of modified reovirus variants in vivo, especially in the same genetic background, will helps us understand the implication of specific modifications in the context of tumors, metastatic sites, and the immune system.

With the advent of efficient reverse genetics approaches, and novel strategies to add exogenous sequences to reovirus, modifications could strive to promote additive features important for reovirus oncolysis. For example, advancements could aim to enhance systemic delivery of reovirus to tumors and metastatic sites. A recent body of literature suggests that blood cells might assist in transport of reovirus to tumors [184-186]. Replication-competent reovirus could be recovered from peripheral blood mononuclear cells, granulocytes, and platelets following intravenous administration in human patients. Once the molecular mechanisms of cell carriage are unravelled, modifications to reovirus that promote association with specific immune cells could promote this process. To test the importance of systemic reovirus clearance by pre-existing and post-treatment neutralizing antibodies, variants of reovirus could be created with changes in immunodominant epitopes and administered in successive cycles of treatment. 
The therapeutic value of reovirus, like other oncolytic viruses, also depends on stimulation of anti-tumor immunity for tumor clearance and hopefully reduced reoccurrence [187-196]. Accordingly, advancements to reovirus should also strive to promote anti-tumor immunity. For example, the ability of cancer therapies to promote immunogenic cell death (ICD), where immune-stimulating danger-associated molecular patterns (PAMPs) are exposed by dying tumor cells, is emerging as an important hallmark of therapeutic potency [197-205]. While some oncolytic viruses are suggested to induce ICD, this is not an intuitive consequence of viral infections since viruses tend to evolve strategies to dodge immune detection. It is therefore important that we learn whether reovirus induces immunogenic cell death in tumors, and if modifications could enhance reovirus' immunotherapeutic value. Finally, additional measures of safety and potency could be introduced into reovirus, such as riboswitches [206,207], prodrug converting enzymes or suicide genes (e.g., ganciclovir-sensitizing HSV thymidine kinase), or miRNA-sensitive sequences. Advantageous modifications could then be combined into united platforms that are most-potent and most-safe, thereby exploiting the true multimodal capacity of viruses. Concurrent advancements in combination-therapy strategies and antitumor immune stimulation will provide a most-optimal regimen and hopefully, a sustained response.

Acknowledgments: We thank the Reoviridae research community for valued discussions on reovirus biology and the Oncolytic Virus research community for vigorously pursuing innovation. We are grateful to the many government, not-for-profit, and industrial sources of funding for research on reovirus and oncolytic virotherapy referenced in this review, and the public for continued support of research and education. Maya Shmulevitz is a Canada Research Chair in Molecular Virology and Oncotherapy, and receives salary support from the Canada Research Chairs Program. Adil Mohamed is a recipient of scholarships from the Alberta Cancer Foundation and the UA Faculty of Medicine and Dentistry.

Conflicts of Interest: The authors declare no conflict of interest.

\section{References}

1. Rosen, L. Serologic grouping of reoviruses by hemagglutination-inhibition. Am. J. Epidemiol. 1960, 71, 242-249.

2. Drayna, D.; Fields, B.N. Activation and characterization of the reovirus transcriptase: Genetic analysis. J. Virol. 1982, 41, 110-118. [PubMed]

3. Adams, D.J.; Ridinger, D.N.; Spendlove, R.S.; Barnett, B.B. Protamine precipitation of two reovirus particle types from polluted waters. Appl. Environ. Microbiol. 1982, 44, 589-596. [PubMed]

4. Hrdy, D.B.; Rosen, L.; Fields, B.N. Polymorphism of the migration of double-stranded RNA genome segments of reovirus isolates from humans, cattle, and mice. J. Virol. 1979, 31, 104-111. [PubMed]

5. Dermody, T.S.; Nibert, M.L.; Bassel-Duby, R.; Fields, B.N. Sequence diversity in S1 genes and S1 translation products of 11 serotype 3 reovirus strains. J. Virol. 1990, 64, 4842-4850. [PubMed]

6. Irving, L.G.; Smith, F.A. One-year survey of enteroviruses, adenoviruses, and reoviruses isolated from effluent at an activated-sludge purification plant. Appl. Environ. Microbiol. 1981, 41, 51-59. [PubMed]

7. Ridinger, D.N.; Spendlove, R.S.; Barnett, B.B.; George, D.B.; Roth, J.C. Evaluation of cell lines and immunofluorescence and plaque assay procedures for quantifying reoviruses in sewage. Appl. Environ. Microbiol. 1982, 43, 740-746. [PubMed]

8. Sedmak, G.; Bina, D.; Macdonald, J.; Couillard, L. Nine-year study of the occurrence of culturable viruses in source water for two drinking water treatment plants and the influent and effluent of a Wastewater Treatment Plant in Milwaukee, Wisconsin (August 1994 through July 2003). Appl. Environ. Microbiol. 2005, 71, 1042-1050. [CrossRef] [PubMed]

9. Minuk, G.Y.; Paul, R.W.; Lee, P.W. The prevalence of antibodies to reovirus type 3 in adults with idiopathic cholestatic liver disease. J. Med. Virol. 1985, 16, 55-60. [CrossRef] [PubMed]

10. Rosen, L.; Evans, H.E.; Spickard, A. Reovirus infections in human volunteers. Am. J. Hyg. 1963, 77, 29-37. [PubMed]

11. Tai, J.H.; Williams, J.V.; Edwards, K.M.; Wright, P.F.; Crowe, J.E., Jr.; Dermody, T.S. Prevalence of reovirus-specific antibodies in young children in Nashville, Tennessee. J. Infect. Dis. 2005, 191, 1221-1224. [CrossRef] [PubMed] 
12. Amerongen, H.M.; Wilson, G.A.; Fields, B.N.; Neutra, M.R. Proteolytic processing of reovirus is required for adherence to intestinal M cells. J. Virol. 1994, 68, 8428-8432. [PubMed]

13. Helander, A.; Silvey, K.J.; Mantis, N.J.; Hutchings, A.B.; Chandran, K.; Lucas, W.T.; Nibert, M.L.; Neutra, M.R. The viral $\sigma 1$ protein and glycoconjugates containing $\alpha 2-3$-linked sialic acid are involved in type 1 reovirus adherence to M cell apical surfaces. J. Virol. 2003, 77, 7964-7977. [CrossRef] [PubMed]

14. Organ, E.L.; Rubin, D.H. Pathogenesis of reovirus gastrointestinal and hepatobiliary disease. Curr. Top. Microbiol. Immunol. 1998, 233, 67-83. [PubMed]

15. Wolf, J.L.; Rubin, D.H.; Finberg, R.; Kauffman, R.S.; Sharpe, A.H.; Trier, J.S.; Fields, B.N. Intestinal M cells: A pathway for entry of reovirus into the host. Science 1981, 212, 471-472. [CrossRef] [PubMed]

16. Rubin, D.H.; Kornstein, M.J.; Anderson, A.O. Reovirus serotype 1 intestinal infection: A novel replicative cycle with ileal disease. J. Virol. 1985, 53, 391-398. [PubMed]

17. Rubin, D.H. Reovirus serotype 1 binds to the basolateral membrane of intestinal epithelial cells. Microb. Pathog. 1987, 3, 215-219. [CrossRef]

18. Barton, E.S.; Forrest, J.C.; Connolly, J.L.; Chappell, J.D.; Liu, Y.; Schnell, F.J.; Nusrat, A.; Parkos, C.A.; Dermody, T.S. Junction adhesion molecule is a receptor for reovirus. Cell 2001, 104, 441-451. [CrossRef]

19. Nibert, M.L.; Chappell, J.D.; Dermody, T.S. Infectious subvirion particles of reovirus type 3 Dearing exhibit a loss in infectivity and contain a cleaved $\sigma 1$ protein. J. Virol. 1995, 69, 5057-5067. [PubMed]

20. Cleveland, D.R.; Zarbl, H.; Millward, S. Reovirus guanylyltransferase is L2 gene product lambda 2. J. Virol. 1986, 60, 307-311. [PubMed]

21. Kim, J.; Parker, J.S.; Murray, K.E.; Nibert, M.L. Nucleoside and RNA triphosphatase activities of orthoreovirus transcriptase cofactor $\mu 2$. J. Biol. Chem. 2004, 279, 4394-4403. [CrossRef] [PubMed]

22. Bisaillon, M.; Lemay, G. Characterization of the reovirus $\lambda 1$ protein RNA $5^{\prime}$-triphosphatase activity. J. Biol. Chem. 1997, 272, 29954-29957. [CrossRef] [PubMed]

23. Kelly, E.; Russell, S.J. History of oncolytic viruses: Genesis to genetic engineering. Mol. Ther. 2007, 15, 651-659. [CrossRef] [PubMed]

24. Hashiro, G.; Loh, P.C.; Yau, J.T. The preferential cytotoxicity of reovirus for certain transformed cell lines. Arch. Virol. 1977, 54, 307-315. [CrossRef] [PubMed]

25. Duncan, M.R.; Stanish, S.M.; Cox, D.C. Differential sensitivity of normal and transformed human cells to reovirus infection. J. Virol. 1978, 28, 444-449. [PubMed]

26. Coffey, M.C.; Strong, J.E.; Forsyth, P.A.; Lee, P.W. Reovirus therapy of tumors with activated Ras pathway. Science 1998, 282, 1332-1334. [CrossRef] [PubMed]

27. Strong, J.E.; Coffey, M.C.; Tang, D.; Sabinin, P.; Lee, P.W. The molecular basis of viral oncolysis: Usurpation of the Ras signaling pathway by reovirus. EMBO J. 1998, 17, 3351-3362. [CrossRef] [PubMed]

28. Hahn, W.C.; Counter, C.M.; Lundberg, A.S.; Beijersbergen, R.L.; Brooks, M.W.; Weinberg, R.A. Creation of human tumour cells with defined genetic elements. Nature 1999, 400, 464-468. [PubMed]

29. Marcato, P.; Shmulevitz, M.; Pan, D.; Stoltz, D.; Lee, P.W. Ras transformation mediates reovirus oncolysis by enhancing virus uncoating, particle infectivity, and apoptosis-dependent release. Mol. Ther. 2007, 15, 1522-1530. [CrossRef] [PubMed]

30. Alain, T.; Kim, T.S.; Lun, X.; Liacini, A.; Schiff, L.A.; Senger, D.L.; Forsyth, P.A. Proteolytic disassembly is a critical determinant for reovirus oncolysis. Mol. Ther. 2007, 15, 1512-1521. [CrossRef] [PubMed]

31. Smakman, N.; van den Wollenberg, D.J.; Borel, R.I.; Hoeben, R.C.; Kranenburg, O. Sensitization to apoptosis underlies KrasD12-dependent oncolysis of murine C26 colorectal carcinoma cells by reovirus T3D. J. Virol. 2005, 79, 14981-14985. [CrossRef] [PubMed]

32. Shmulevitz, M.; Pan, L.Z.; Garant, K.; Pan, D.; Lee, P.W. Oncogenic Ras promotes reovirus spread by suppressing IFN-beta production through negative regulation of RIG-I signaling. Cancer Res. 2010, 70, 4912-4921. [CrossRef] [PubMed]

33. Rudd, P.; Lemay, G. Correlation between interferon sensitivity of reovirus isolates and ability to discriminate between normal and Ras-transformed cells. J. Gen. Virol. 2005, 86, 1489-1497. [CrossRef] [PubMed]

34. Errington, F.; White, C.L.; Twigger, K.R.; Rose, A.; Scott, K.; Steele, L.; Ilett, L.J.; Prestwich, R.; Pandha, H.S.; Coffey, M.; et al. Inflammatory tumour cell killing by oncolytic reovirus for the treatment of melanoma. Gene Ther. 2008, 15, 1257-1270. [CrossRef] [PubMed] 
35. Etoh, T.; Himeno, Y.; Matsumoto, T.; Aramaki, M.; Kawano, K.; Nishizono, A.; Kitano, S. Oncolytic viral therapy for human pancreatic cancer cells by reovirus. Clin. Cancer Res. 2003, 9, 1218-1223. [PubMed]

36. Hirasawa, K.; Nishikawa, S.G.; Norman, K.L.; Alain, T.; Kossakowska, A.; Lee, P.W. Oncolytic reovirus against ovarian and colon cancer. Cancer Res. 2002, 62, 1696-1701. [PubMed]

37. Ikeda, Y.; Nishimura, G.; Yanoma, S.; Kubota, A.; Furukawa, M.; Tsukuda, M. Reovirus oncolysis in human head and neck squamous carcinoma cells. Auris Nasus Larynx 2004, 31, 407-412. [CrossRef]

38. Norman, K.L.; Coffey, M.C.; Hirasawa, K.; Demetrick, D.J.; Nishikawa, S.G.; DiFrancesco, L.M.; Strong, J.E.; Lee, P.W. Reovirus oncolysis of human breast cancer. Hum. Gene Ther. 2002, 13, 641-652. [CrossRef] [PubMed]

39. Comins, C.; Spicer, J.; Protheroe, A.; Roulstone, V.; Twigger, K.; White, C.M.; Vile, R.; Melcher, A.; Coffey, M.C.; Mettinger, K.L.; et al. REO-10, a phase I study of intravenous reovirus and docetaxel in patients with advanced cancer. Clin. Cancer Res. 2010, 16, 5564-5572. [CrossRef] [PubMed]

40. Forsyth, P.; Roldan, G.; George, D.; Wallace, C.; Palmer, C.A.; Morris, D.; Cairncross, G.; Matthews, M.V.; Markert, J.; Gillespie, Y.; et al. A phase I trial of intratumoral administration of reovirus in patients with histologically confirmed recurrent malignant gliomas. Mol. Ther. 2008, 16, 627-632. [CrossRef] [PubMed]

41. Harrington, K.J.; Karapanagiotou, E.M.; Roulstone, V.; Twigger, K.R.; White, C.L.; Vidal, L.; Beirne, D.; Prestwich, R.; Newbold, K.; Ahmed, M.; et al. Two-stage phase I dose-escalation study of intratumoral reovirus type 3 dearing and palliative radiotherapy in patients with advanced cancers. Clin. Cancer Res. 2010, 16, 3067-3077. [CrossRef] [PubMed]

42. Karapanagiotou, E.M.; Roulstone, V.; Twigger, K.; Ball, M.; Tanay, M.; Nutting, C.; Newbold, K.; Gore, M.E.; Larkin, J.; Syrigos, K.N.; et al. Phase I/II trial of carboplatin and paclitaxel chemotherapy in combination with intravenous oncolytic reovirus in patients with advanced malignancies. Clin. Cancer Res. 2012, 18, 2080-2089. [CrossRef] [PubMed]

43. Lolkema, M.P.; Arkenau, H.T.; Harrington, K.; Roxburgh, P.; Morrison, R.; Roulstone, V.; Twigger, K.; Coffey, M.; Mettinger, K.; Gill, G.; et al. A phase I study of the combination of intravenous reovirus type 3 Dearing and gemcitabine in patients with advanced cancer. Clin. Cancer Res. 2011, 17, 581-588. [CrossRef] [PubMed]

44. Vidal, L.; Pandha, H.S.; Yap, T.A.; White, C.L.; Twigger, K.; Vile, R.G.; Melcher, A.; Coffey, M.; Harrington, K.J.; Debono, J.S. A phase I study of intravenous oncolytic reovirus type 3 Dearing in patients with advanced cancer. Clin. Cancer Res. 2008, 14, 7127-7137. [CrossRef] [PubMed]

45. White, C.L.; Twigger, K.R.; Vidal, L.; de Bono, J.S.; Coffey, M.; Heinemann, L.; Morgan, R.; Merrick, A.; Errington, F.; Vile, R.G.; et al. Characterization of the adaptive and innate immune response to intravenous oncolytic reovirus (Dearing type 3) during a phase I clinical trial. Gene Ther. 2008, 15, 911-920. [CrossRef] [PubMed]

46. Gollamudi, R.; Ghalib, M.H.; Desai, K.K.; Chaudhary, I.; Wong, B.; Einstein, M.; Coffey, M.; Gill, G.M.; Mettinger, K.; Mariadason, J.M.; et al. Intravenous administration of Reolysin, a live replication competent RNA virus is safe in patients with advanced solid tumors. Invest. New Drugs 2010, 28, 641-649. [CrossRef] [PubMed]

47. Phase 3 Trial Examining REOLYSIN ${ }^{\circledR}$ in Combination with Paclitaxel and Carboplatin in Patients with Platinum-Refractory Head and Neck Cancers. Oncolytics Biotech Inc., 2011. Available online: http:/ / www.oncolyticsbiotech.com/clinical_pr.html (accessed on 26 November 2015).

48. Heinemann, L.; Simpson, G.R.; Boxall, A.; Kottke, T.; Relph, K.L.; Vile, R.; Melcher, A.; Prestwich, R.; Harrington, K.J.; Morgan, R.; et al. Synergistic effects of oncolytic reovirus and docetaxel chemotherapy in prostate cancer. BMC Cancer 2011, 11. [CrossRef] [PubMed]

49. Harrington, K.J.; Melcher, A.; Vassaux, G.; Pandha, H.S.; Vile, R.G. Exploiting synergies between radiation and oncolytic viruses. Curr. Opin. Mol. Ther. 2008, 10, 362-370. [PubMed]

50. Harrington, K.J.; Vile, R.G.; Melcher, A.; Chester, J.; Pandha, H.S. Clinical trials with oncolytic reovirus: Moving beyond phase I into combinations with standard therapeutics. Cytokine Growth Factor Rev. 2010, 21, 91-98. [CrossRef] [PubMed]

51. Rajani, K.; Parrish, C.; Kottke, T.; Thompson, J.; Zaidi, S.; Ilett, L.; Shim, K.G.; Diaz, R.M.; Pandha, H.; Harrington, K.; et al. Combination therapy with reovirus and anti-PD-1 blockade controls tumor growth through innate and adaptive immune responses. Mol. Ther. 2015. [CrossRef] [PubMed] 
52. Hartmann, D.M.; Grin, I.; Dunin-Horkawicz, S.; Deiss, S.; Linke, D.; Lupas, A.N.; Hernandez, A.B. Complete fiber structures of complex trimeric autotransporter adhesins conserved in enterobacteria. Proc. Natl. Acad. Sci. USA 2012, 109, 20907-20912. [CrossRef] [PubMed]

53. Reiter, D.M.; Frierson, J.M.; Halvorson, E.E.; Kobayashi, T.; Dermody, T.S.; Stehle, T. Crystal structure of reovirus attachment protein $\sigma 1$ in complex with sialylated oligosaccharides. PLoS. Pathog. 2011, 7, e1002166. [CrossRef] [PubMed]

54. Kirchner, E.; Guglielmi, K.M.; Strauss, H.M.; Dermody, T.S.; Stehle, T. Structure of reovirus $\sigma 1$ in complex with its receptor junctional adhesion molecule-A. PLoS Pathog. 2008, 4, e1000235. [CrossRef] [PubMed]

55. Leone, G.; Mah, D.C.; Lee, P.W. The incorporation of reovirus cell attachment protein $\sigma 1$ into virions requires the N-terminal hydrophobic tail and the adjacent heptad repeat region. Virology 1991, 182, 346-350. [CrossRef]

56. Leone, G.; Duncan, R.; Mah, D.C.; Price, A.; Cashdollar, L.W.; Lee, P.W. The N-terminal heptad repeat region of reovirus cell attachment protein $\sigma 1$ is responsible for $\sigma 1$ oligomer stability and possesses intrinsic oligomerization function. Virology 1991, 182, 336-345. [CrossRef]

57. Barton, E.S.; Connolly, J.L.; Forrest, J.C.; Chappell, J.D.; Dermody, T.S. Utilization of sialic acid as a coreceptor enhances reovirus attachment by multistep adhesion strengthening. J. Biol. Chem. 2001, 276, 2200-2211. [CrossRef] [PubMed]

58. Chappell, J.D.; Barton, E.S.; Smith, T.H.; Baer, G.S.; Duong, D.T.; Nibert, M.L.; Dermody, T.S. Cleavage susceptibility of reovirus attachment protein $\sigma 1$ during proteolytic disassembly of virions is determined by a sequence polymorphism in the $\sigma 1$ neck. J. Virol. 1998, 72, 8205-8213. [PubMed]

59. Campbell, J.A.; Schelling, P.; Wetzel, J.D.; Johnson, E.M.; Forrest, J.C.; Wilson, G.A.; Aurrand-Lions, M.; Imhof, B.A.; Stehle, T.; Dermody, T.S. Junctional adhesion molecule a serves as a receptor for prototype and field-isolate strains of mammalian reovirus. J. Virol. 2005, 79, 7967-7978. [CrossRef] [PubMed]

60. Prota, A.E.; Campbell, J.A.; Schelling, P.; Forrest, J.C.; Watson, M.J.; Peters, T.R.; Aurrand-Lions, M.; Imhof, B.A.; Dermody, T.S.; Stehle, T. Crystal structure of human junctional adhesion molecule 1: Implications for reovirus binding. Proc. Natl. Acad. Sci. USA 2003, 100, 5366-5371. [CrossRef] [PubMed]

61. Konopka-Anstadt, J.L.; Mainou, B.A.; Sutherland, D.M.; Sekine, Y.; Strittmatter, S.M.; Dermody, T.S. The Nogo receptor NgR1 mediates infection by mammalian reovirus. Cell Host Microbe 2014, 15, 681-691. [CrossRef] [PubMed]

62. Maginnis, M.S.; Forrest, J.C.; Kopecky-Bromberg, S.A.; Dickeson, S.K.; Santoro, S.A.; Zutter, M.M.; Nemerow, G.R.; Bergelson, J.M.; Dermody, T.S. $\beta 1$ integrin mediates internalization of mammalian reovirus. J. Virol. 2006, 80, 2760-2770. [CrossRef] [PubMed]

63. Maginnis, M.S.; Mainou, B.A.; Derdowski, A.; Johnson, E.M.; Zent, R.; Dermody, T.S. NPXY motifs in the $\beta 1$ integrin cytoplasmic tail are required for functional reovirus entry. J. Virol. 2008, 82, 3181-3191. [CrossRef] [PubMed]

64. Stencel-Baerenwald, J.E.; Reiss, K.; Reiter, D.M.; Stehle, T.; Dermody, T.S. The sweet spot: Defining virus-sialic acid interactions. Nat. Rev. Microbiol. 2014, 12, 739-749. [CrossRef] [PubMed]

65. Gentsch, J.R.; Pacitti, A.F. Differential interaction of reovirus type 3 with sialylated receptor components on animal cells. Virology 1987, 161, 245-248. [CrossRef]

66. Gentsch, J.R.; Pacitti, A.F. Effect of neuraminidase treatment of cells and effect of soluble glycoproteins on type 3 reovirus attachment to murine L cells. J. Virol. 1985, 56, 356-364. [PubMed]

67. Paul, R.W.; Choi, A.H.; Lee, P.W. The alpha-anomeric form of sialic acid is the minimal receptor determinant recognized by reovirus. Virology 1989, 172, 382-385. [CrossRef]

68. Chappell, J.D.; Gunn, V.L.; Wetzel, J.D.; Baer, G.S.; Dermody, T.S. Mutations in type 3 reovirus that determine binding to sialic acid are contained in the fibrous tail domain of viral attachment protein $\sigma 1$. J. Virol. 1997, 71, 1834-1841. [PubMed]

69. Chappell, J.D.; Duong, J.L.; Wright, B.W.; Dermody, T.S. Identification of carbohydrate-binding domains in the attachment proteins of type 1 and type 3 reoviruses. J. Virol. 2000, 74, 8472-8479. [CrossRef] [PubMed]

70. Reiss, K.; Stencel, J.E.; Liu, Y.; Blaum, B.S.; Reiter, D.M.; Feizi, T.; Dermody, T.S.; Stehle, T. The GM2 glycan serves as a functional coreceptor for serotype 1 reovirus. PLoS. Pathog. 2012, 8, e1003078. [CrossRef] [PubMed] 
71. Barton, E.S.; Youree, B.E.; Ebert, D.H.; Forrest, J.C.; Connolly, J.L.; Valyi-Nagy, T.; Washington, K.; Wetzel, J.D.; Dermody, T.S. Utilization of sialic acid as a coreceptor is required for reovirus-induced biliary disease. J. Clin. Invest. 2003, 111, 1823-1833. [CrossRef] [PubMed]

72. Frierson, J.M.; Pruijssers, A.J.; Konopka, J.L.; Reiter, D.M.; Abel, T.W.; Stehle, T.; Dermody, T.S. Utilization of sialylated glycans as coreceptors enhances the neurovirulence of serotype 3 reovirus. J. Virol. 2012, 86, 13164-13173. [CrossRef] [PubMed]

73. Boligan, K.F.; Mesa, C.; Fernandez, L.E.; von Gunten, S. Cancer intelligence acquired (CIA): Tumor glycosylation and sialylation codes dismantling antitumor defense. Cell Mol. Life Sci. 2015, 72, 1231-1248. [CrossRef] [PubMed]

74. Padler-Karavani, V.; Hurtado-Ziola, N.; Pu, M.; Yu, H.; Huang, S.; Muthana, S.; Chokhawala, H.A.; Cao, H.; Secrest, P.; Friedmann-Morvinski, D.; et al. Human xeno-autoantibodies against a non-human sialic acid serve as novel serum biomarkers and immunotherapeutics in cancer. Cancer Res. 2011, 71, 3352-3363. [CrossRef] [PubMed]

75. Sandekian, V.; Lemay, G. Amino acids substitutions in $\sigma 1$ and $\mu 1$ outer capsid proteins of a Vero cell-adapted mammalian orthoreovirus are required for optimal virus binding and disassembly. Virus Res. 2015, 196, 20-29. [CrossRef] [PubMed]

76. Jabre, R.; Sandekian, V.; Lemay, G. Amino acid substitutions in $\sigma 1$ and $\mu 1$ outer capsid proteins are selected during mammalian reovirus adaptation to Vero cells. Virus Res. 2013, 176, 188-198. [CrossRef] [PubMed]

77. Ebnet, K.; Suzuki, A.; Ohno, S.; Vestweber, D. Junctional adhesion molecules (JAMs): More molecules with dual functions? J. Cell Sci. 2004, 117, 19-29. [CrossRef] [PubMed]

78. Ikeo, K.; Oshima, T.; Shan, J.; Matsui, H.; Tomita, T.; Fukui, H.; Watari, J.; Miwa, H. Junctional adhesion molecule-A promotes proliferation and inhibits apoptosis of gastric cancer. Hepatogastroenterology 2015, 62, 540-545. [PubMed]

79. Tian, Y.; Tian, Y.; Zhang, W.; Wei, F.; Yang, J.; Luo, X.; Zhou, T.; Hou, B.; Qian, S.; Deng, X.; et al. Junctional adhesion molecule-A, an epithelial-mesenchymal transition inducer, correlates with metastasis and poor prognosis in human nasopharyngeal cancer. Carcinogenesis 2015, 36, 41-48. [CrossRef] [PubMed]

80. Zhao, C.; Lu, F.; Chen, H.; Zhao, X.; Sun, J.; Chen, H. Dysregulation of JAM-A plays an important role in human tumor progression. Int. J. Clin. Exp. Pathol. 2014, 7, 7242-7248. [PubMed]

81. Lathia, J.D.; Li, M.; Sinyuk, M.; Alvarado, A.G.; Flavahan, W.A.; Stoltz, K.; Rosager, A.M.; Hale, J.; Hitomi, M.; Gallagher, J.; et al. High-throughput flow cytometry screening reveals a role for junctional adhesion molecule a as a cancer stem cell maintenance factor. Cell Rep. 2014, 6, 117-129. [CrossRef] [PubMed]

82. Zhang, M.; Luo, W.; Huang, B.; Liu, Z.; Sun, L.; Zhang, Q.; Qiu, X.; Xu, K.; Wang, E. Overexpression of JAM-A in non-small cell lung cancer correlates with tumor progression. PLoS. ONE 2013, 8, e79173. [CrossRef] [PubMed]

83. Goetsch, L.; Haeuw, J.F.; Beau-Larvor, C.; Gonzalez, A.; Zanna, L.; Malissard, M.; Lepecquet, A.M.; Robert, A.; Bailly, C.; Broussas, M.; et al. A novel role for junctional adhesion molecule-A in tumor proliferation: Modulation by an anti-JAM-A monoclonal antibody. Int. J. Cancer 2013, 132, 1463-1474. [CrossRef] [PubMed]

84. Murakami, M.; Giampietro, C.; Giannotta, M.; Corada, M.; Torselli, I.; Orsenigo, F.; Cocito, A.; d'Ario, G.; Mazzarol, G.; Confalonieri, S.; et al. Abrogation of junctional adhesion molecule-A expression induces cell apoptosis and reduces breast cancer progression. PLoS ONE 2011, 6, e21242. [CrossRef] [PubMed]

85. Ponten, F.; Jirstrom, K.; Uhlen, M. The Human Protein Atlas-A tool for pathology. J. Pathol. 2008, 216, 387-393. [CrossRef] [PubMed]

86. Uhlen, M.; Bjorling, E.; Agaton, C.; Szigyarto, C.A.; Amini, B.; Andersen, E.; Andersson, A.C.; Angelidou, P.; Asplund, A.; Asplund, C.; et al. A human protein atlas for normal and cancer tissues based on antibody proteomics. Mol. Cell. Proteom. 2005, 4, 1920-1932. [CrossRef] [PubMed]

87. Berglund, L.; Bjorling, E.; Oksvold, P.; Fagerberg, L.; Asplund, A.; Szigyarto, C.A.; Persson, A.; Ottosson, J.; Wernerus, H.; Nilsson, P.; et al. A genecentric Human Protein Atlas for expression profiles based on antibodies. Mol. Cell. Proteom. 2008, 7, 2019-2027. [CrossRef] [PubMed]

88. Uhlen, M.; Oksvold, P.; Fagerberg, L.; Lundberg, E.; Jonasson, K.; Forsberg, M.; Zwahlen, M.; Kampf, C.; Wester, K.; Hober, S.; et al. Towards a knowledge-based Human Protein Atlas. Nat. Biotechnol. 2010, 28, 1248-1250. [CrossRef] [PubMed] 
89. Uhlen, M.; Fagerberg, L.; Hallstrom, B.M.; Lindskog, C.; Oksvold, P.; Mardinoglu, A.; Sivertsson, A.; Kampf, C.; Sjostedt, E.; Asplund, A.; et al. Proteomics. Tissue-based map of the human proteome. Science 2015, 347. [CrossRef] [PubMed]

90. Terasawa, Y.; Hotani, T.; Katayama, Y.; Tachibana, M.; Mizuguchi, H.; Sakurai, F. Activity levels of cathepsins $\mathrm{B}$ and $\mathrm{L}$ in tumor cells are a biomarker for efficacy of reovirus-mediated tumor cell killing. Cancer Gene Ther. 2015, 22, 188-197. [CrossRef] [PubMed]

91. Van Houdt, W.J.; Smakman, N.; van den Wollenberg, D.J.; Emmink, B.L.; Veenendaal, L.M.; van Diest, P.J.; Hoeben, R.C.; Borel, R.I.; Kranenburg, O. Transient infection of freshly isolated human colorectal tumor cells by reovirus T3D intermediate subviral particles. Cancer Gene Ther. 2008, 15, 284-292. [CrossRef] [PubMed]

92. Van den Wollenberg, D.J.; Dautzenberg, I.J.; van den Hengel, S.K.; Cramer, S.J.; de Groot, R.J.; Hoeben, R.C. Isolation of reovirus T3D mutants capable of infecting human tumor cells independent of junction adhesion molecule-A. PLoS ONE 2012, 7, e48064. [CrossRef] [PubMed]

93. Chappell, J.D.; Prota, A.E.; Dermody, T.S.; Stehle, T. Crystal structure of reovirus attachment protein $\sigma 1$ reveals evolutionary relationship to adenovirus fiber. EMBO J. 2002, 21, 1-11. [CrossRef] [PubMed]

94. Mercier, G.T.; Campbell, J.A.; Chappell, J.D.; Stehle, T.; Dermody, T.S.; Barry, M.A. A chimeric adenovirus vector encoding reovirus attachment protein $\sigma 1$ targets cells expressing junctional adhesion molecule 1. Proc. Natl. Acad. Sci. USA 2004, 101, 6188-6193. [CrossRef] [PubMed]

95. Schagen, F.H.; Graat, H.C.; Carette, J.E.; Vellinga, J.; van Geer, M.A.; Hoeben, R.C.; Dermody, T.S.; van Beusechem, V.W. Replacement of native adenovirus receptor-binding sites with a new attachment moiety diminishes hepatic tropism and enhances bioavailability in mice. Hum. Gene Ther. 2008, 19, 783-794. [CrossRef] [PubMed]

96. Tsuruta, Y.; Pereboeva, L.; Glasgow, J.N.; Luongo, C.L.; Komarova, S.; Kawakami, Y.; Curiel, D.T. Reovirus $\sigma 1$ fiber incorporated into adenovirus serotype 5 enhances infectivity via a CAR-independent pathway. Biochem. Biophys. Res. Commun. 2005, 335, 205-214. [CrossRef] [PubMed]

97. Tsuruta, Y.; Pereboeva, L.; Glasgow, J.N.; Rein, D.T.; Kawakami, Y.; Alvarez, R.D.; Rocconi, R.P.; Siegal, G.P.; Dent, P.; Fisher, P.B.; et al. A mosaic fiber adenovirus serotype 5 vector containing reovirus $\sigma 1$ and adenovirus serotype 3 knob fibers increases transduction in an ovarian cancer ex vivo system via a coxsackie and adenovirus receptor-independent pathway. Clin. Cancer Res. 2007, 13, 2777-2783. [CrossRef] [PubMed]

98. Van den Wollenberg, D.J.; van den Hengel, S.K.; Dautzenberg, I.J.; Cramer, S.J.; Kranenburg, O.; Hoeben, R.C. A strategy for genetic modification of the spike-encoding segment of human reovirus T3D for reovirus targeting. Gene Ther. 2008, 15, 1567-1578. [CrossRef] [PubMed]

99. Bass, D.M.; Bodkin, D.; Dambrauskas, R.; Trier, J.S.; Fields, B.N.; Wolf, J.L. Intraluminal proteolytic activation plays an important role in replication of type 1 reovirus in the intestines of neonatal mice. J. Virol. 1990, 64, 1830-1833. [PubMed]

100. Bodkin, D.K.; Nibert, M.L.; Fields, B.N. Proteolytic digestion of reovirus in the intestinal lumens of neonatal mice. J. Virol. 1989, 63, 4676-4681. [PubMed]

101. Jane-Valbuena, J.; Breun, L.A.; Schiff, L.A.; Nibert, M.L. Sites and determinants of early cleavages in the proteolytic processing pathway of reovirus surface protein $\sigma 3$. J. Virol. 2002, 76, 5184-5197. [CrossRef] [PubMed]

102. Borsa, J.; Sargent, M.D.; Ewing, D.D.; Einspenner, M. Perturbation of the switch-on of transcriptase activity in intermediate subviral particles from reovirus. J. Cell. Physiol. 1982, 112, 10-18. [CrossRef] [PubMed]

103. Nibert, M.L.; Odegard, A.L.; Agosto, M.A.; Chandran, K.; Schiff, L.A. Putative autocleavage of reovirus mu1 protein in concert with outer-capsid disassembly and activation for membrane permeabilization. J. Mol. Biol. 2005, 345, 461-474. [CrossRef] [PubMed]

104. Odegard, A.L.; Chandran, K.; Zhang, X.; Parker, J.S.; Baker, T.S.; Nibert, M.L. Putative autocleavage of outer capsid protein micro1, allowing release of myristoylated peptide micro1N during particle uncoating, is critical for cell entry by reovirus. J. Virol. 2004, 78, 8732-8745. [CrossRef] [PubMed]

105. Borsa, J.; Sargent, M.D.; Lievaart, P.A.; Copps, T.P. Reovirus: Evidence for a second step in the intracellular uncoating and transcriptase activation process. Virology 1981, 111, 191-200. [CrossRef]

106. Chandran, K.; Farsetta, D.L.; Nibert, M.L. Strategy for nonenveloped virus entry: A hydrophobic conformer of the reovirus membrane penetration protein micro 1 mediates membrane disruption. J. Virol. 2002, 76, 9920-9933. [CrossRef] [PubMed] 
107. Chandran, K.; Parker, J.S.; Ehrlich, M.; Kirchhausen, T.; Nibert, M.L. The delta region of outer-capsid protein micro 1 undergoes conformational change and release from reovirus particles during cell entry. J. Virol. 2003, 77, 13361-13375. [CrossRef] [PubMed]

108. Dryden, K.A.; Wang, G.; Yeager, M.; Nibert, M.L.; Coombs, K.M.; Furlong, D.B.; Fields, B.N.; Baker, T.S. Early steps in reovirus infection are associated with dramatic changes in supramolecular structure and protein conformation: Analysis of virions and subviral particles by cryoelectron microscopy and image reconstruction. J. Cell Biol. 1993, 122, 1023-1041. [CrossRef] [PubMed]

109. Sarkar, P.; Danthi, P. Determinants of strain-specific differences in efficiency of reovirus entry. J. Virol. 2010, 84, 12723-12732. [CrossRef] [PubMed]

110. Agosto, M.A.; Myers, K.S.; Ivanovic, T.; Nibert, M.L. A positive-feedback mechanism promotes reovirus particle conversion to the intermediate associated with membrane penetration. Proc. Natl. Acad. Sci. USA 2008, 105, 10571-10576. [CrossRef] [PubMed]

111. Agosto, M.A.; Ivanovic, T.; Nibert, M.L. Mammalian reovirus, a nonfusogenic nonenveloped virus, forms size-selective pores in a model membrane. Proc. Natl. Acad. Sci. USA 2006, 103, 16496-16501. [CrossRef] [PubMed]

112. Danthi, P.; Guglielmi, K.M.; Kirchner, E.; Mainou, B.; Stehle, T.; Dermody, T.S. From touchdown to transcription: The reovirus cell entry pathway. Curr. Top. Microbiol. Immunol. 2010, 343, 91-119. [PubMed]

113. Danthi, P.; Holm, G.H.; Stehle, T.; Dermody, T.S. Reovirus receptors, cell entry, and proapoptotic signaling. Adv. Exp. Med. Biol. 2013, 790, 42-71. [PubMed]

114. Mainou, B.A.; Dermody, T.S. In search of cathepsins: How reovirus enters host cells. DNA Cell Biol. 2012, 31, 1646-1649. [CrossRef] [PubMed]

115. Ebert, D.H.; Deussing, J.; Peters, C.; Dermody, T.S. Cathepsin L and cathepsin B mediate reovirus disassembly in murine fibroblast cells. J. Biol. Chem. 2002, 277, 24609-24617. [CrossRef] [PubMed]

116. Johnson, E.M.; Doyle, J.D.; Wetzel, J.D.; McClung, R.P.; Katunuma, N.; Chappell, J.D.; Washington, M.K.; Dermody, T.S. Genetic and pharmacologic alteration of cathepsin expression influences reovirus pathogenesis. J. Virol. 2009, 83, 9630-9640. [CrossRef] [PubMed]

117. Golden, J.W.; Schiff, L.A. Neutrophil elastase, an acid-independent serine protease, facilitates reovirus uncoating and infection in U937 promonocyte cells. Virol. J. 2005, 2. [CrossRef] [PubMed]

118. Golden, J.W.; Bahe, J.A.; Lucas, W.T.; Nibert, M.L.; Schiff, L.A. Cathepsin S supports acid-independent infection by some reoviruses. J. Biol. Chem. 2004, 279, 8547-8557. [CrossRef] [PubMed]

119. Nygaard, R.M.; Golden, J.W.; Schiff, L.A. Impact of host proteases on reovirus infection in the respiratory tract. J. Virol. 2012, 86, 1238-1243. [CrossRef] [PubMed]

120. Ma, W.; Tang, C.; Lai, L. Specificity of trypsin and chymotrypsin: Loop-motion-controlled dynamic correlation as a determinant. Biophys. J. 2005, 89, 1183-1193. [CrossRef] [PubMed]

121. McGrath, M.E. The lysosomal cysteine proteases. Annu. Rev. Biophys. Biomol. Struct. 1999, 28, $181-204$. [CrossRef] [PubMed]

122. Vajda, T.; Szabo, T. Specificity of trypsin and alpha-chymotrypsin towards neutral substrates. Acta Biochim. Biophys. Acad. Sci. Hung. 1976, 11, 287-294. [PubMed]

123. Golden, J.W.; Linke, J.; Schmechel, S.; Thoemke, K.; Schiff, L.A. Addition of exogenous protease facilitates reovirus infection in many restrictive cells. J. Virol. 2002, 76, 7430-7443. [CrossRef] [PubMed]

124. Dautzenberg, I.J.; van den Wollenberg, D.J.; van den Hengel, S.K.; Limpens, R.W.; Barcena, M.; Koster, A.J.; Hoeben, R.C. Mammalian orthoreovirus T3D infects U-118 MG cell spheroids independent of junction adhesion molecule-A. Gene Ther. 2014, 21, 609-617. [CrossRef] [PubMed]

125. Middleton, J.K.; Severson, T.F.; Chandran, K.; Gillian, A.L.; Yin, J.; Nibert, M.L. Thermostability of reovirus disassembly intermediates (ISVPs) correlates with genetic, biochemical, and thermodynamic properties of major surface protein $\mu 1$. J. Virol. 2002, 76, 1051-1061. [CrossRef] [PubMed]

126. Liemann, S.; Chandran, K.; Baker, T.S.; Nibert, M.L.; Harrison, S.C. Structure of the reovirus membrane-penetration protein, M1, in a complex with is protector protein, $\sigma 3$. Cell 2002, 108, 283-295. [CrossRef]

127. Metcalf, P.; Cyrklaff, M.; Adrian, M. The three-dimensional structure of reovirus obtained by cryo-electron microscopy. EMBO J. 1991, 10, 3129-3136. [PubMed]

128. Olland, A.M.; Jane-Valbuena, J.; Schiff, L.A.; Nibert, M.L.; Harrison, S.C. Structure of the reovirus outer capsid and dsRNA-binding protein $\sigma 3$ at 1.8 A resolution. EMBO J. 2001, 20, 979-989. [CrossRef] [PubMed] 
129. Shepard, D.A.; Ehnstrom, J.G.; Schiff, L.A. Association of reovirus outer capsid proteins $\sigma 3$ and $\mu 1$ causes a conformational change that renders $\sigma 3$ protease sensitive. J. Virol. 1995, 69, 8180-8184. [PubMed]

130. Clark, K.M.; Wetzel, J.D.; Gu, Y.; Ebert, D.H.; McAbee, S.A.; Stoneman, E.K.; Baer, G.S.; Zhu, Y.; Wilson, G.J.; Prasad, B.V.; et al. Reovirus variants selected for resistance to ammonium chloride have mutations in viral outer-capsid protein $\sigma 3$. J. Virol. 2006, 80, 671-681. [CrossRef] [PubMed]

131. Wetzel, J.D.; Wilson, G.J.; Baer, G.S.; Dunnigan, L.R.; Wright, J.P.; Tang, D.S.; Dermody, T.S. Reovirus variants selected during persistent infections of L cells contain mutations in the viral S1 and S4 genes and are altered in viral disassembly. J. Virol. 1997, 71, 1362-1369. [PubMed]

132. Wilson, G.J.; Nason, E.L.; Hardy, C.S.; Ebert, D.H.; Wetzel, J.D.; Prasad, B.V.V.; Dermody, T.S. A single mutation in the carboxy terminus of reovirus outer-capsid protein $\sigma 3$ confers enhanced kinetics of $\sigma 3$ proteolysis, resistance to inhibitors of viral disassembly, and alterations in $\sigma 3$ structure. J. Virol. 2002, 76, 9832-9843. [CrossRef] [PubMed]

133. Doyle, J.D.; Danthi, P.; Kendall, E.A.; Ooms, L.S.; Wetzel, J.D.; Dermody, T.S. Molecular determinants of proteolytic disassembly of the reovirus outer capsid. J. Biol. Chem. 2012, 287, 8029-8038. [CrossRef] [PubMed]

134. Wilson, G.J.; Wetzel, J.D.; Puryear, W.; Bassel-Duby, R.; Dermody, T.S. Persistent reovirus infections of L cells select mutations in viral attachment protein $\sigma 1$ that alter oligomer stability. J. Virol. 1996, 70, 6598-6606. [PubMed]

135. Doyle, J.D.; Stencel-Baerenwald, J.E.; Copeland, C.A.; Rhoads, J.P.; Brown, J.J.; Boyd, K.L.; Atkinson, J.B.; Dermody, T.S. Diminished reovirus capsid stability alters disease pathogenesis and littermate transmission. PLoS. Pathog. 2015, 11, e1004693. [CrossRef] [PubMed]

136. Denzler, K.L.; Jacobs, B.L. Site-directed mutagenic analysis of reovirus $\sigma 3$ protein binding to dsRNA. Virology 1994, 204, 190-199. [CrossRef] [PubMed]

137. Yue, Z.; Shatkin, A.J. Double-stranded RNA-dependent protein kinase (PKR) is regulated by reovirus structural proteins. Virology 1997, 234, 364-371. [CrossRef] [PubMed]

138. Madren, J.A.; Sarkar, P.; Danthi, P. Cell entry-associated conformational changes in reovirus particles are controlled by host protease activity. J. Virol. 2012, 86, 3466-3473. [CrossRef] [PubMed]

139. Sarkar, P.; Danthi, P. The $\mu 1$ 72-96 loop controls conformational transitions during reovirus cell entry. J. Virol. 2013, 87, 13532-13542. [CrossRef] [PubMed]

140. Shmulevitz, M.; Gujar, S.A.; Ahn, D.G.; Mohamed, A.; Lee, P.W. Reovirus variants with mutations in S1 and L2 genome segments exhibit enhanced virion infectivity and superior oncolysis. J. Virol. 2012, 86, 7403-7413. [CrossRef] [PubMed]

141. Chandran, K.; Walker, S.B.; Chen, Y.; Contreras, C.M.; Schiff, L.A.; Baker, T.S.; Nibert, M.L. In vitro recoating of reovirus cores with baculovirus-expressed outer-capsid proteins $\mu 1$ and $\sigma 3$. J. Virol. 1999, 73, 3941-3950. [PubMed]

142. Mendez, I.I.; Weiner, S.G.; She, Y.M.; Yeager, M.; Coombs, K.M. Conformational changes accompany activation of reovirus RNA-dependent RNA transcription. J. Struct. Biol. 2008, 162, 277-289. [CrossRef] [PubMed]

143. Reinisch, K.M.; Nibert, M.L.; Harrison, S.C. Structure of the reovirus core at 3.6 A resolution. Nature 2000, 404, 960-967. [PubMed]

144. Tao, Y.; Farsetta, D.L.; Nibert, M.L.; Harrison, S.C. RNA synthesis in a cage-Structural studies of reovirus polymerase $\lambda 3$. Cell 2002, 111, 733-745. [CrossRef]

145. Zhang, X.; Jin, L.; Fang, Q.; Hui, W.H.; Zhou, Z.H. 3.3 A cryo-EM structure of a nonenveloped virus reveals a priming mechanism for cell entry. Cell 2010, 141, 472-482. [CrossRef] [PubMed]

146. Zhang, X.; Walker, S.B.; Chipman, P.R.; Nibert, M.L.; Baker, T.S. Reovirus polymerase $\lambda 3$ localized by cryo-electron microscopy of virions at a resolution of 7.6 A. Nat. Struct. Biol. 2003, 10, 1011-1018. [CrossRef] [PubMed]

147. Mohamed, A.; Teicher, C.; Haefliger, S.; Shmulevitz, M. Reduction of virion-associated $\sigma 1$ fibers on oncolytic reovirus variants promotes adaptation toward tumorigenic cells. J. Virol. 2015, 89, 4319-4334. [CrossRef] [PubMed]

148. Larson, S.M.; Antczak, J.B.; Joklik, W.K. Reovirus exists in the form of 13 particle species that differ in their content of protein $\sigma 1$. Virology 1994, 201, 303-311. [CrossRef] [PubMed] 
149. Kim, M.; Garant, K.A.; zur Nieden, N.I.; Alain, T.; Loken, S.D.; Urbanski, S.J.; Forsyth, P.A.; Rancourt, D.E.; Lee, P.W.; Johnston, R.N. Attenuated reovirus displays oncolysis with reduced host toxicity. Br. J. Cancer 2011, 104, 290-299. [CrossRef] [PubMed]

150. Kim, M.; Egan, C.; Alain, T.; Urbanski, S.J.; Lee, P.W.; Forsyth, P.A.; Johnston, R.N. Acquired resistance to reoviral oncolysis in Ras-transformed fibrosarcoma cells. Oncogene 2007, 26, 4124-4134. [CrossRef] [PubMed]

151. Antar, A.A.; Konopka, J.L.; Campbell, J.A.; Henry, R.A.; Perdigoto, A.L.; Carter, B.D.; Pozzi, A.; Abel, T.W.; Dermody, T.S. Junctional adhesion molecule-A is required for hematogenous dissemination of reovirus. Cell Host Microbe 2009, 5, 59-71. [CrossRef] [PubMed]

152. Connolly, J.L.; Barton, E.S.; Dermody, T.S. Reovirus binding to cell surface sialic acid potentiates virus-induced apoptosis. J. Virol. 2001, 75, 4029-4039. [CrossRef] [PubMed]

153. Beattie, E.; Kauffman, E.B.; Martinez, H.; Perkus, M.E.; Jacobs, B.L.; Paoletti, E.; Tartaglia, J. Host-range restriction of vaccinia virus E3L-specific deletion mutants. Virus Genes 1996, 12, 89-94. [CrossRef] [PubMed]

154. Imani, F.; Jacobs, B.L. Inhibitory activity for the interferon-induced protein kinase is associated with the reovirus serotype $1 \sigma 3$ protein. Proc. Natl. Acad. Sci. USA 1988, 85, 7887-7891. [CrossRef] [PubMed]

155. Jacobs, B.L.; Langland, J.O. Reovirus $\sigma 3$ protein: dsRNA binding and inhibition of RNA-activated protein kinase. Curr. Top. Microbiol. Immunol. 1998, 233, 185-196. [PubMed]

156. Mabrouk, T.; Danis, C.; Lemay, G. Two basic motifs of reovirus $\sigma 3$ protein are involved in double-stranded RNA binding. Biochem. Cell Biol. 1995, 73, 137-145. [CrossRef] [PubMed]

157. Irvin, S.C.; Zurney, J.; Ooms, L.S.; Chappell, J.D.; Dermody, T.S.; Sherry, B. A single amino acid polymorphism in reovirus protein M2 determines repression of interferon signaling and modulates myocarditis. J. Virol. 2012, 86, 2302-2311. [CrossRef] [PubMed]

158. Zurney, J.; Kobayashi, T.; Holm, G.H.; Dermody, T.S.; Sherry, B. Reovirus $\mu 2$ protein inhibits interferon signaling through a novel mechanism involving nuclear accumulation of interferon regulatory factor 9. J. Virol. 2009, 83, 2178-2187. [CrossRef] [PubMed]

159. Sherry, B.; Torres, J.; Blum, M.A. Reovirus induction of and sensitivity to beta interferon in cardiac myocyte cultures correlate with induction of myocarditis and are determined by viral core proteins. J. Virol. 1998, 72, 1314-1323. [PubMed]

160. Cheng, G.; Feng, Z.; He, B. Herpes simplex virus 1 infection activates the endoplasmic reticulum resident kinase PERK and mediates eIF-2alpha dephosphorylation by the gamma(1)34.5 protein. J. Virol. 2005, 79, 1379-1388. [CrossRef] [PubMed]

161. Cheng, G.; Yang, K.; He, B. Dephosphorylation of eIF-2alpha mediated by the gamma(1)34.5 protein of herpes simplex virus type 1 is required for viral response to interferon but is not sufficient for efficient viral replication. J. Virol. 2003, 77, 10154-10161. [CrossRef] [PubMed]

162. Li, Y.; Zhang, C.; Chen, X.; Yu, J.; Wang, Y.; Yang, Y.; Du, M.; Jin, H.; Ma, Y.; He, B.; et al. ICP34.5 protein of herpes simplex virus facilitates the initiation of protein translation by bridging eukaryotic initiation factor 2alpha (eIF2alpha) and protein phosphatase 1. J. Biol. Chem. 2011, 286, 24785-24792. [CrossRef] [PubMed]

163. Ma, Y.; Jin, H.; Valyi-Nagy, T.; Cao, Y.; Yan, Z.; He, B. Inhibition of TANK binding kinase 1 by herpes simplex virus 1 facilitates productive infection. J. Virol. 2012, 86, 2188-2196. [CrossRef] [PubMed]

164. Grekova, S.; Zawatzky, R.; Horlein, R.; Cziepluch, C.; Mincberg, M.; Davis, C.; Rommelaere, J.; Daeffler, L. Activation of an antiviral response in normal but not transformed mouse cells: A new determinant of minute virus of mice oncotropism. J. Virol. 2010, 84, 516-531. [CrossRef] [PubMed]

165. Stojdl, D.F.; Lichty, B.; Knowles, S.; Marius, R.; Atkins, H.; Sonenberg, N.; Bell, J.C. Exploiting tumor-specific defects in the interferon pathway with a previously unknown oncolytic virus. Nat. Med. 2000, 6, 821-825. [PubMed]

166. Krishnamurthy, S.; Takimoto, T.; Scroggs, R.A.; Portner, A. Differentially regulated interferon response determines the outcome of Newcastle disease virus infection in normal and tumor cell lines. J. Virol. 2006, 80, 5145-5155. [CrossRef] [PubMed]

167. Miller, J.E.; Samuel, C.E. Proteolytic cleavage of the reovirus $\sigma 3$ protein results in enhanced double-stranded RNA-binding activity: Identification of a repeated basic amino acid motif within the C-terminal binding region. J. Virol. 1992, 66, 5347-5356. [PubMed]

168. Schiff, L.A. Reovirus capsid proteins $\sigma 3$ and $\mu 1$ : Interactions that influence viral entry, assembly, and translational control. Curr. Top. Microbiol. Immunol. 1998, 233, 167-183. [PubMed] 
169. Bergeron, J.; Mabrouk, T.; Garzon, S.; Lemay, G. Characterization of the thermosensitive ts453 reovirus mutant: Increased dsRNA binding of $\sigma 3$ protein correlates with interferon resistance. Virology 1998, 246, 199-210. [CrossRef] [PubMed]

170. Chandran, K.; Zhang, X.; Olson, N.H.; Walker, S.B.; Chappell, J.D.; Dermody, T.S.; Baker, T.S.; Nibert, M.L. Complete in vitro assembly of the reovirus outer capsid produces highly infectious particles suitable for genetic studies of the receptor-binding protein. J. Virol. 2001, 75, 5335-5342. [CrossRef] [PubMed]

171. Roner, M.R.; Joklik, W.K. Reovirus reverse genetics: Incorporation of the CAT gene into the reovirus genome. Proc. Natl. Acad. Sci. USA 2001, 98, 8036-8041. [CrossRef] [PubMed]

172. Roner, M.R.; Bassett, K.; Roehr, J. Identification of the $5^{\prime}$ sequences required for incorporation of an engineered ssRNA into the Reovirus genome. Virology 2004, 329, 348-360. [CrossRef] [PubMed]

173. Roner, M.R.; Roehr, J. The $3^{\prime}$ sequences required for incorporation of an engineered ssRNA into the Reovirus genome. Virol. J. 2006, 3. [CrossRef] [PubMed]

174. Roner, M.R.; Steele, B.G. Features of the mammalian orthoreovirus 3 Dearing 11 single-stranded RNA that direct packaging and serotype restriction. J. Gen. Virol. 2007, 88, 3401-3412. [CrossRef] [PubMed]

175. Roner, M.R.; Steele, B.G. Localizing the reovirus packaging signals using an engineered $\mathrm{m} 1$ and s2 ssRNA. Virology 2007, 358, 89-97. [CrossRef] [PubMed]

176. Baric, R.S.; Sims, A.C. A Reverse genetics system for dsRNA viruses. Cell Host Microbe 2007, 1, 90-91. [CrossRef] [PubMed]

177. Kobayashi, T.; Antar, A.A.; Boehme, K.W.; Danthi, P.; Eby, E.A.; Guglielmi, K.M.; Holm, G.H.; Johnson, E.M.; Maginnis, M.S.; Naik, S.; et al. A plasmid-based reverse genetics system for animal double-stranded RNA viruses. Cell Host Microbe 2007, 1, 147-157. [CrossRef] [PubMed]

178. Kobayashi, T.; Ooms, L.S.; Ikizler, M.; Chappell, J.D.; Dermody, T.S. An improved reverse genetics system for mammalian orthoreoviruses. Virology 2010, 398, 194-200. [CrossRef] [PubMed]

179. Komoto, S.; Kawagishi, T.; Kobayashi, T.; Ikizler, M.; Iskarpatyoti, J.; Dermody, T.S.; Taniguchi, K. A plasmid-based reverse genetics system for mammalian orthoreoviruses driven by a plasmid-encoded T7 RNA polymerase. J. Virol. Methods 2014, 196, 36-39. [CrossRef] [PubMed]

180. Demidenko, A.A.; Blattman, J.N.; Blattman, N.N.; Greenberg, P.D.; Nibert, M.L. Engineering recombinant reoviruses with tandem repeats and a tetravirus 2A-like element for exogenous polypeptide expression. Proc. Natl. Acad. Sci. USA 2013, 110, E1867-E1876. [CrossRef] [PubMed]

181. Van den Wollenberg, D.J.; Dautzenberg, I.J.; Ros, W.; Lipinska, A.D.; van den Hengel, S.K.; Hoeben, R.C. Replicating reoviruses with a transgene replacing the codons for the head domain of the viral spike. Gene Ther. 2015, 22, 51-63. [CrossRef] [PubMed]

182. Brochu-Lafontaine, V.; Lemay, G. Addition of exogenous polypeptides on the mammalian reovirus outer capsid using reverse genetics. J. Virol. Methods 2012, 179, 342-350. [CrossRef] [PubMed]

183. Rouault, E.; Lemay, G. Incorporation of epitope-tagged viral $\sigma 3$ proteins to reovirus virions. Can. J. Microbiol. 2003, 49, 407-417. [CrossRef] [PubMed]

184. Adair, R.A.; Scott, K.J.; Fraser, S.; Errington-Mais, F.; Pandha, H.; Coffey, M.; Selby, P.; Cook, G.P.; Vile, R.; Harrington, K.J.; et al. Cytotoxic and immune-mediated killing of human colorectal cancer by reovirus-loaded blood and liver mononuclear cells. Int. J. Cancer 2013, 132, 2327-2338. [CrossRef] [PubMed]

185. Adair, R.A.; Roulstone, V.; Scott, K.J.; Morgan, R.; Nuovo, G.J.; Fuller, M.; Beirne, D.; West, E.J.; Jennings, V.A.; Rose, A.; et al. Cell carriage, delivery, and selective replication of an oncolytic virus in tumor in patients. Sci. Transl. Med. 2012, 4. [CrossRef] [PubMed]

186. Ilett, E.J.; Prestwich, R.J.; Kottke, T.; Errington, F.; Thompson, J.M.; Harrington, K.J.; Pandha, H.S.; Coffey, M.; Selby, P.J.; Vile, R.G.; et al. Dendritic cells and T cells deliver oncolytic reovirus for tumour killing despite pre-existing anti-viral immunity. Gene Ther. 2009, 16, 689-699. [CrossRef] [PubMed]

187. Clements, D.R.; Sterea, A.M.; Kim, Y.; Helson, E.; Dean, C.A.; Nunokawa, A.; Coyle, K.M.; Sharif, T.; Marcato, P.; Gujar, S.A.; et al. Newly recruited CD11b+, GR-1+, Ly6C(high) myeloid cells augment tumor-associated immunosuppression immediately following the therapeutic administration of oncolytic reovirus. J. Immunol. 2015, 194, 4397-4412. [CrossRef] [PubMed]

188. Gujar, S.; Dielschneider, R.; Clements, D.; Helson, E.; Shmulevitz, M.; Marcato, P.; Pan, D.; Pan, L.Z.; Ahn, D.G.; Alawadhi, A.; et al. Multifaceted therapeutic targeting of ovarian peritoneal carcinomatosis through virus-induced immunomodulation. Mol. Ther. 2013, 21, 338-347. [CrossRef] [PubMed] 
189. Gujar, S.A.; Marcato, P.; Pan, D.; Lee, P.W. Reovirus virotherapy overrides tumor antigen presentation evasion and promotes protective antitumor immunity. Mol. Cancer Ther. 2010, 9, 2924-2933. [CrossRef] [PubMed]

190. Gujar, S.A.; Pan, D.A.; Marcato, P.; Garant, K.A.; Lee, P.W. Oncolytic virus-initiated protective immunity against prostate cancer. Mol. Ther. 2011, 19, 797-804. [CrossRef] [PubMed]

191. Gujar, S.A.; Lee, P.W. Oncolytic virus-mediated reversal of impaired tumor antigen presentation. Front. Oncol. 2014, 4. [CrossRef] [PubMed]

192. Prestwich, R.J.; Errington, F.; Ilett, E.J.; Morgan, R.S.; Scott, K.J.; Kottke, T.; Thompson, J.; Morrison, E.E.; Harrington, K.J.; Pandha, H.S.; et al. Tumor infection by oncolytic reovirus primes adaptive antitumor immunity. Clin. Cancer Res. 2008, 14, 7358-7366. [CrossRef] [PubMed]

193. Prestwich, R.J.; Errington, F.; Hatfield, P.; Merrick, A.E.; Ilett, E.J.; Selby, P.J.; Melcher, A.A. The immune system-Is it relevant to cancer development, progression and treatment? Clin. Oncol. 2008, 20, 101-112. [CrossRef] [PubMed]

194. Prestwich, R.J.; Errington, F.; Steele, L.P.; Ilett, E.J.; Morgan, R.S.; Harrington, K.J.; Pandha, H.S.; Selby, P.J.; Vile, R.G.; Melcher, A.A. Reciprocal human dendritic cell-natural killer cell interactions induce antitumor activity following tumor cell infection by oncolytic reovirus. J. Immunol. 2009, 183, 4312-4321. [CrossRef] [PubMed]

195. Prestwich, R.J.; Ilett, E.J.; Errington, F.; Diaz, R.M.; Steele, L.P.; Kottke, T.; Thompson, J.; Galivo, F.; Harrington, K.J.; Pandha, H.S.; et al. Immune-mediated antitumor activity of reovirus is required for therapy and is independent of direct viral oncolysis and replication. Clin. Cancer Res. 2009, 15, 4374-4381. [CrossRef] [PubMed]

196. Steele, L.; Errington, F.; Prestwich, R.; Ilett, E.; Harrington, K.; Pandha, H.; Coffey, M.; Selby, P.; Vile, R.; Melcher, A. Pro-inflammatory cytokine/chemokine production by reovirus treated melanoma cells is PKR/NF-kappaB mediated and supports innate and adaptive anti-tumour immune priming. Mol. Cancer 2011, 10. [CrossRef] [PubMed]

197. Angelova, A.L.; Grekova, S.P.; Heller, A.; Kuhlmann, O.; Soyka, E.; Giese, T.; Aprahamian, M.; Bour, G.; Ruffer, S.; Cziepluch, C.; et al. Complementary induction of immunogenic cell death by oncolytic parvovirus H-1PV and gemcitabine in pancreatic cancer. J. Virol. 2014, 88, 5263-5276. [CrossRef] [PubMed]

198. Donnelly, O.G.; Errington-Mais, F.; Steele, L.; Hadac, E.; Jennings, V.; Scott, K.; Peach, H.; Phillips, R.M.; Bond, J.; Pandha, H.; et al. Measles virus causes immunogenic cell death in human melanoma. Gene Ther. 2013, 20, 7-15. [CrossRef] [PubMed]

199. Jiang, H.; Fueyo, J. Healing after death: Antitumor immunity induced by oncolytic adenoviral therapy. Oncoimmunology 2014, 3, e947872. [CrossRef] [PubMed]

200. Kepp, O.; Senovilla, L.; Vitale, I.; Vacchelli, E.; Adjemian, S.; Agostinis, P.; Apetoh, L.; Aranda, F.; Barnaba, V.; Bloy, N.; et al. Consensus guidelines for the detection of immunogenic cell death. Oncoimmunology 2014, 3. [CrossRef] [PubMed]

201. Koks, C.A.; Garg, A.D.; Ehrhardt, M.; Riva, M.; Vandenberk, L.; Boon, L.; de Vleeschouwer, S.; Agostinis, P.; Graf, N.; van Gool, S.W. Newcastle disease virotherapy induces long-term survival and tumor-specific immune memory in orthotopic glioma through the induction of immunogenic cell death. Int. J. Cancer 2015, 136, E313-E325. [CrossRef] [PubMed]

202. Miyamoto, S.; Inoue, H.; Nakamura, T.; Yamada, M.; Sakamoto, C.; Urata, Y.; Okazaki, T.; Marumoto, T.; Takahashi, A.; Takayama, K.; et al. Coxsackievirus B3 is an oncolytic virus with immunostimulatory properties that is active against lung adenocarcinoma. Cancer Res. 2012, 72, 2609-2621. [CrossRef] [PubMed]

203. Workenhe, S.T.; Pol, J.G.; Lichty, B.D.; Cummings, D.T.; Mossman, K.L. Combining oncolytic HSV-1 with immunogenic cell death-inducing drug mitoxantrone breaks cancer immune tolerance and improves therapeutic efficacy. Cancer Immunol. Res. 2013, 1, 309-319. [CrossRef] [PubMed]

204. Workenhe, S.T.; Mossman, K.L. Rewiring cancer cell death to enhance oncolytic viro-immunotherapy. Oncoimmunology 2013, 2. [CrossRef] [PubMed]

205. Workenhe, S.T.; Mossman, K.L. Oncolytic virotherapy and immunogenic cancer cell death: Sharpening the sword for improved cancer treatment strategies. Mol. Ther. 2014, 22, 251-256. [CrossRef] [PubMed] 
206. Ketzer, P.; Kaufmann, J.K.; Engelhardt, S.; Bossow, S.; von Kalle, C.; Hartig, J.S.; Ungerechts, G.; Nettelbeck, D.M. Artificial riboswitches for gene expression and replication control of DNA and RNA viruses. Proc. Natl. Acad. Sci. USA 2014, 111, E554-E562. [CrossRef] [PubMed]

207. Strobel, B.; Klauser, B.; Hartig, J.S.; Lamla, T.; Gantner, F.; Kreuz, S. Riboswitch-mediated attenuation of transgene cytotoxicity increases adeno-associated virus vector yields in HEK-293 cells. Mol. Ther. 2015. [CrossRef] [PubMed]

(c) (C) 2015 by the authors; licensee MDPI, Basel, Switzerland. This article is an open access article distributed under the terms and conditions of the Creative Commons by Attribution (CC-BY) license (http://creativecommons.org/licenses/by/4.0/). 